\title{
Troškovi i koristi zaduživanja države u stranoj valuti : je li ono izvor ranjivosti za članice EU-a izvan eurozone?
}

Brkić, Mislav

Source / Izvornik: Odabrani prijevodi, 2021, 12, 1 - 28

Journal article, Published version

Rad u časopisu, Objavljena verzija rada (izdavačev PDF)

https://doi.org/10.3326/op.55

Permanent link / Trajna poveznica: https://urn.nsk.hr/urn:nbn:hr:242:395079

Rights / Prava: Attribution-NonCommercial-NoDerivatives 4.0 International/ImenovanjeNekomercijalno-Bez prerada 4.0 međunarodna

Download date / Datum preuzimanja: 2023-04-26

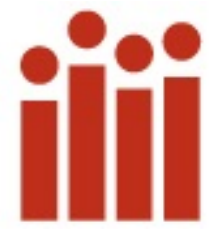

Repository / Repozitorij:

Institute of Public Finance Repository

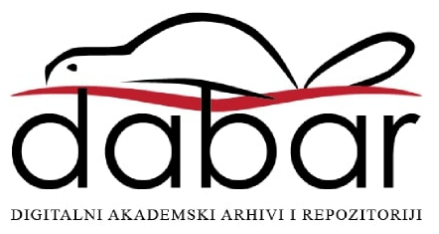


Institut za

javne financije

Smičiklasova 21 | Zagreb

www.ijf.hr | ured@ijf.hr

\section{TROŠKOVI I KORISTI ZADUŽIVANJA DRŽAVE U STRANOJ VALUTI: JE LI ONO IZVOR RANJIVOSTI ZA ČLANICE EU-A IZVAN EUROZONE?}

MISLAV BRKIĆ, UNIV. SPEC. OEC.*

\section{ODABRANI \\ PRIJEVODI}

\section{BR. 55}

\section{1.}

ISSN: 1847-7445

doi: $10.3326 /$ op

\section{citirati:}

Brkić M., 2021. Costs and benefits

of government borrowing in

foreign currency: is it a major

source of risk for EU member

states outside the Euro? Public

Sector Economics, 45(1),

str. 63-91.

https://doi.org/10.3326.pse.45.1.2

\author{
PREGLEDNI ČLANAK ${ }^{*}$ \\ JEL: E52, E58, F34, H63 \\ DOI: $10.3326 /$ OP.55
}

\section{SAŽETAK}

Ovaj se rad bavi troškovima i koristima zaduživanja države u stranoj valuti. Osim što razmatra glavne troškove, kao što su povećana izloženost valutnom riziku i riziku refinanciranja te smanjena sposobnost države da intervenira u slučaju izbijanja financijske krize, rad opisuje i koristi od zaduživanja u stranoj valuti. Također ispituje i u kojoj se mjeri države članice EU-a koje nisu uvele euro oslanjaju na zaduživanje u stranoj valuti i imaju li dovoljno kapaciteta za očuvanje stabilnosti svojih valuta u slučaju negativnih šokova. Analiza otkriva da javne financije tih država nisu znatno izložene valutnom riziku. Iznimke su Bugarska i Hrvatska, čiji je javni dug većinom nominiran u eurima, a koje su ujedno ranjive i zbog visoke razine depozitne $i$ kreditne euroizacije. Stoga ne iznenađuje činjenica da su upravo Bugarska i Hrvatska prve poduzele odlučne korake u smjeru uvođenja eura.

Ključne riječi: strana valuta, javni dug, međunarodne pričuve, dužnička kriza, dolarizacija

\footnotetext{
* Autor zahvaljuje kolegi Igoru Ljubaju i anonimnim recenzentima na korisnim komentarima tijekom izrade ovog rada.

** Primljeno: 16. 6. 2020.

Prihvaćeno: 10. 11. 2020.
}

Mislav BRKIĆ

Hrvatska narodna banka, Trg hrvatskih velikana 3, 10000 Zagreb, Hrvatska email: mislav.brkic@hnb.hr

ORCID: 0000-0003-3872-4824 


\section{UvOD}

Od 1970-ih mnogo se puta pokazalo da zaduživanje države u stranoj valuti može biti značajan izvor rizika. Ne samo da zaduživanje u stranoj valuti stvara valutnu neusklađenost i tako izlaže javne financije tečajnim šokovima nego i refinanciranje javnog duga može biti zahtjevnije. Naime, svjesni da je država ranjiva zbog valutne neusklađenosti, investitori mogu biti vrlo osjetljivi na promjene u percipiranoj rizičnosti države. Ako se percepcija rizičnosti države pogorša, vlasnici njezinih obveznica mogu ih odlučiti prodati kako bi izbjegli moguće gubitke ukoliko država ne uspije pribaviti dovoljno deviza za otplatu duga u stranoj valuti. U takvim uvjetima, refinanciranje obveza koje dospijevaju može za državu postati neizvedivo. Dakle, država snažno zadužena u stranoj valuti ranjiva je na „samoispunjavajuća proročanstva“: zabrinutost investitora da država više neće moći otplaćivati dug lako može dovesti do toga da država zaista ne bude u mogućnosti podmiriti svoj dug.

lako nas ekonomska povijest upozorava da zaduživanje u stranoj valuti može biti vrlo štetno za makroekonomsku stabilnost, i danas se mnoge države uvelike oslanjaju na financiranje u stranoj valuti. Jedan od ciljeva ovog rada je objasniti koji su razlozi za to. Osim što se raspravlja o troškovima i rizicima, opisuju se i dvije ključne koristi zaduživanja u stranoj valuti, koje su osobito vidljive u malim, visoko dolariziranim državama. Jedna je to što su izvori financiranja u ključnim svjetskim valutama obično izdašniji i jeftiniji od lokalnih izvora financiranja u domaćoj valuti. Stoga, u državama u kojima su lokalni izvori financiranja oskudni, inozemno zaduživanje države, ako su sredstva usmjerena u produktivne projekte, može biti važan pokretač gospodarskog rasta i razvoja. Druga korist proizlazi iz toga što zaduživanje države u stranoj valuti omogućuje središnjoj banci - barem privremeno, dok se razina javnog duga povećava - da akumulira međunarodne pričuve koje podupiru stabilnost domaće valute. Kao argument ovoj tvrdnji, u radu se pokazuje kako je zaduživanje države u stranoj valuti indirektno „zaslužno“ za gotovo $40 \%$ ukupnog povećanja međunarodnih pričuva Hrvatske u protekla dva desetljeća.

Drugi cilj ovog rada je ispitati u kojoj se mjeri države članice EU-a koje nisu uvele euro oslanjaju na zaduživanje u stranoj valuti te imaju li dovoljno kapaciteta za očuvanje stabilnosti svojih valuta u slučaju negativnog šoka. Analiza upućuje na to da javne financije tih država nisu znatno izložene valutnom riziku. $U$ većini njih glavnina javnog duga nominirana je u domaćoj valuti, što znači da su javne financije uglavnom neosjetljive na tečajna kretanja. Iznimke su Bugarska i Hrvatska čiji se javni dug pretežno sastoji od obveza nominiranih u eurima. S obzirom na njihovu relativno veću izloženost valutnom riziku, ne iznenađuje činjenica da su upravo Bugarska i Hrvatska prve poduzele konkretne korake u smjeru uvođenja eura. Treba napomenuti da su zahvaljujući povoljnim fiskalnim i vanjskim ostvarenjima čak i ove dvije države ublažile svoju ranjivost na valutni rizik. To se očitovalo 2020. nakon izbijanja pandemije virusa COVID-19, kada su obje države uspješno očuvale stabilnost svojih valuta unatoč snažnim negativnim ekonomskim učincima mjera za suzbijanje širenja zaraze.

Najvažniji doprinos ovog rada je što daje uravnoteženi pregled troškova i koristi zaduživanja države u stranoj valuti. lako zaduživanje u stranoj valuti čini državu ranjivom i stoga se treba 
izbjegavati ako je moguće, ovaj rad pokazuje da u nekim posebnim slučajevima - primjerice kada je financijski sustav visoko euroiziran (dolariziran) - ono zapravo može biti poželjno iz perspektive financijske stabilnosti. Također, na temelju analize valutne strukture javnog duga država članica EU-a izvan eurozone u radu se daje potencijalno objašnjenje zašto neke od njih žele uvesti euro, a neke ne.

Rad je strukturiran na sljedeći način. Drugo poglavlje razmatra glavne nedostatke i neke prednosti zaduživanja države u stranoj valuti iz perspektive država s tržištima u nastajanju, uzimajući u obzir specifična obilježja njihovih gospodarstava. Treće poglavlje predstavlja relevantnu literaturu koja daje odgovor na pitanje kako država koja se znatno oslanja na zaduživanje u stranoj valuti može umanjiti rizik valutne i dužničke krize. Četvrto poglavlje analizira valutnu strukturu javnog duga i druge makroekonomske pokazatelje država članica EU-a izvan eurozone te na temelju toga ocjenjuje je li za njih zaduživanje u stranoj valuti značajan izvor rizika. Članak završava zaključkom.

\section{TROŠKOVI I KORISTI ZADUŽIVANJA DRŽAVE U STRANOJ VALUTI 2.1. TROŠKOVI ZADUŽIVANJA U STRANOJ VALUTI}

\subsubsection{Izloženost valutnom riziku}

Ako je valutna pozicija dužnika neusklađena, zaduživanje u stranoj valuti je rizično jer čini dužnika osjetljivim na fluktuacije deviznog tečaja. Primjerice, ako se država zadužuje na financijskim tržištima u stranoj valuti, dok (porezne) prihode ostvaruje isključivo u domaćoj valuti, bit će ranjiva na moguću deprecijaciju domaće valute. U slučaju deprecijacije omjer javnog duga i BDP-a će porasti, kao i kamatni izdaci, što će negativno djelovati na proračunski saldo. Ako su država, poduzeća i kućanstva istodobno zaduženi u stranoj valuti, cijelo gospodarstvo bit će znatno izloženo valutnom riziku.

Postoji opsežna literatura o uzrocima i posljedicama zaduživanja u stranoj valuti. U utjecajnom radu, Eichengreen i Hausmann (1999.) utvrdili su da većina zemalja u razvoju nije u mogućnosti izdavati inozemni dug u domaćoj valuti, pa im preostaje jedino plasirati dužničke instrumente nominirane u jednoj od ključnih svjetskih valuta. Nemogućnost zaduživanja u inozemstvu u domaćoj valuti ovi autori nazivaju „the original sin“ jer zbog toga nastaje valutna neusklađenost na agregatnoj razini, koja predstavlja znatno ograničenje za nositelje ekonomskih politika. Naime, u uvjetima visoke izloženosti domaćih sektora valutnom riziku, očuvanje stabilnosti domaće valute u pravilu postaje glavni prioritet za središnju banku. Potpuna usredotočenost na stabilnost tečaja, međutim, smanjuje prostor za fleksibilno korištenje monetarne politike jer ostali ciljevi, kao što je upravljanje poslovnim ciklusom, postaju manje važni (Eichengreen, Hausmann i Panizza, 2003.). Posljedično, države koje se u velikoj mjeri zadužuju u stranoj valuti često bilježe viši stupanj makroekonomske volatilnosti od onih koje se pretežno zadužuju u vlastitoj valuti.

Utjecaj deprecijacije tečaja na javne financije vrlo je izravan. Dio javnog duga nominiran u stranoj valuti ili vezan uz stranu valutu mehanički će porasti (u terminima domaće valute) u slučaju jačanja strane valute što će dovesti do povećanja omjera javnog duga i BDP-a (Grafikon 1.). Osim toga, kao odraz povećanja razine duga, povećat će se i godišnji 
proračunski izdaci za kamate, čak i ako prosječna kamatna stopa na dug ostane nepromijenjena. Međutim, vrlo je vjerojatno da će nakon snažne deprecijacije domaće valute premija rizika za državu postati viša i tako učiniti svako novo zaduživanje države skupljim. Ovo bi nadalje proizvelo sekundarne učinke jer bi viša prosječna kamatna stopa na dug značila još veće izdatke za kamate, s nepovoljnim utjecajem na proračunski saldo i dinamiku javnog duga.

\section{Grafikon 1.}

Utjecaj deprecijacije tečaja na javne financije

\section{a) bruto dug države, u \% BDP-a}

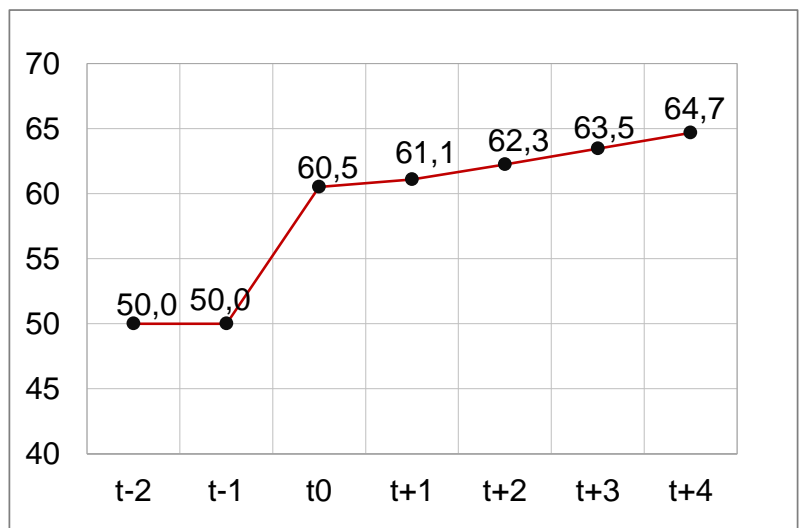

b) proračunski saldo, u \% BDP-a

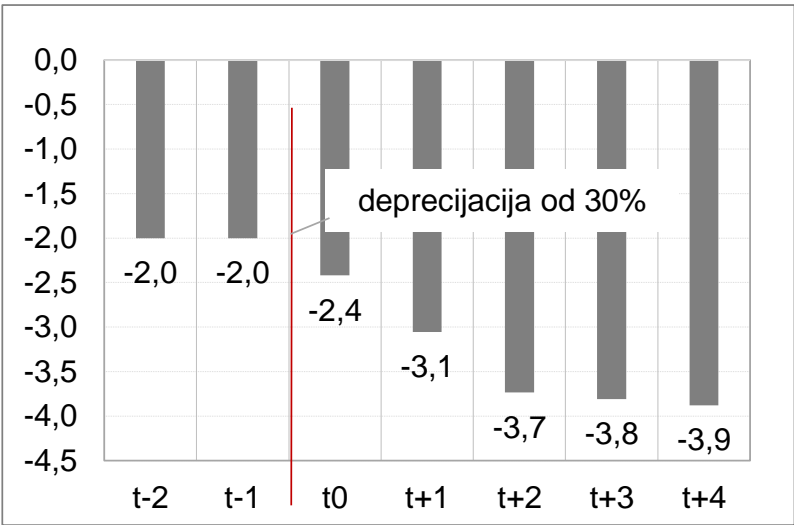

Napomena: Simulacija je napravljena s pretpostavkom da početni omjer duga i BDP-a iznosi 50\%, da je primarni manjak nula, udio duga u stranoj valuti u ukupnom dugu iznosi 70\%, stopa rasta nominalnog BDP-a iznosi $4 \%$, dok se ponderirana kamatna stopa na dug, koja inicijalno iznosi $4 \%$, nakon deprecijacije tečaja povećava na $5 \%$ u $t+1$ te na $6 \%$ u t+2, nakon čega ostaje stabilna.

Izvor: Autor

Što bi moglo uzrokovati deprecijaciju tečaja u državi koja se intenzivno zadužuje u stranoj valuti? Mnogo činitelja može dovesti do takvog ishoda, pri čemu je ranjivost bankovnog sustava jedan od najčešćih okidača. ${ }^{1}$ Primjerice, ako banke imaju velike nepokrivene kratkoročne obveze u stranoj valuti, odluka većeg broja vjerovnika i deponenata da opozovu svoje kredite odnosno povuku svoje depozite proizvela bi snažan pritisak na ograničene zalihe likvidne devizne imovine banaka (Chang i Velasco, 1999.). Kao posljedica relativne nestašice strane u odnosu na ponudu domaće valute, domaća valuta bi počela slabjeti, što bi primoralo središnju banku da upotrijebi međunarodne pričuve i tako pokuša stabilizirati tečaj. Ekstreman primjer ovakvog scenarija bila je financijska kriza na Islandu 2008. Taj događaj jasno je pokazao kako prevelik i loše reguliran bankovni sustav može upropastiti valutu i ekonomiju zemlje u cijelosti (Claessens, Herring i Schoenmaker, 2010.). Nadalje, deprecijacija tečaja može se dogoditi ako investitori, zabrinuti zbog pogoršanih makroekonomskih pokazatelja zemlje ${ }^{2}$ ili napuhanih cijena imovine, počnu likvidirati svoje pozicije u državnim obveznicama i

\footnotetext{
${ }^{1}$ Kaminsky i Reinhart (1999.) empirijski su istražile povezanost bankovnih i valutnih kriza. Utvrdile su da se bankovne i valutne krize često odvijaju usporedno, pri čemu bankovna kriza u pravilu nastupa prije valutne krize. Valutna kriza povratno pojačava bankovnu krizu, kreirajući negativnu povratnu spregu koja snažno pogađa realno gospodarstvo. Međutim, iako bankovne krize obično izbijaju prije valutnih kriza, one nisu nužno njihov uzročnik. Zapravo, dvije krize su ponekad odraz istog temeljnog uzročnika - prekomjernog kreditnog rasta podržanog povoljnim pristupom međunarodnim financijskim tržištima.

${ }^{2}$ Frankel i Rose (1996.) pronašli su da je vjerojatnost izbijanja valutne krize visoka kada su međunarodne pričuve skromne, kada je udio izravnih inozemnih ulaganja u ukupnom inozemnom dugu nizak, kada je realni tečaj
} 
drugim vrijednosnicama nominiranima u domaćoj valuti. Rizik da rasprodaja imovine nominirane u domaćoj valuti ugrozi stabilnost valute manji je u državama s plitkim tržištima kapitala. U takvim državama ponuda vrijednosnica u domaćoj valuti je oskudna, pa je mali rizik da će transakcije na tržištu kapitala proizvesti snažne deprecijacijske pritiske na valutu.

\subsubsection{Povećanje rizika refinanciranja}

Osim što izlaže dužnika valutnom riziku, zaduživanje u stranoj valuti povezano je i s većim rizikom refinanciranja. Zapravo, ta se dva rizika mogu međusobno pojačavati. Primjerice, valutni rizik može povećati rizik refinanciranja, na način da velika prisutnost valutnog rizika može sama po sebi biti okidač za materijalizaciju rizika refinanciranja. Ta veza je vrlo intuitivna: ako se država zadužuje u stranoj valuti, njezini vjerovnici bit će posredno izloženi valutnom riziku jer snažna deprecijacija domaće valute može smanjiti sposobnost države da podmiruje svoje obveze u stranoj valuti. ${ }^{3}$ Stoga, u slučaju da vjerovnici posumnjaju da bi valuta te države mogla oslabjeti, oni ju više ne bi bili voljni financirati. Posljedično, država bi bila primorana otplaćivati glavnicu duga u stranoj valuti kako dug dospijeva, što bi, ako veliki iznosi moraju biti otplaćeni u kratkom razdoblju, moglo dovesti do dužničke ili valutne krize. U takvim uvjetima jedino što državi preostaje - ako želi izbjeći obustavu otplate duga (default) je zatražiti međunarodnu financijsku pomoć.

Postoje brojni povijesni primjeri dužničkih kriza uzrokovanih prekomjernim zaduživanjem u stranoj valuti. Zapravo, financijskim krizama u državama s tržištima u nastajanju u pravilu prethode razdoblja obilnog priljeva inozemnog financiranja u stranoj valuti. Naime, ako su globalni financijski uvjeti povoljni, države s tržištima u nastajanju imat će poticaj uvoziti kapital iz inozemstva kako bi financirale domaću potrošnju i investicije po niskim kamatnim stopama. Pozitivan učinak što ga potrošnja financirana inozemnim kapitalom ima na BDP i zaposlenost nadalje se pozitivno odražava na potrošački i poslovni optimizam i tako rezultira još većom sklonošću zaduživanju i potrošnji. Ako se ne suzbije razboritim ekonomskim politikama, prekomjerno inozemno zaduživanje može dovesti do neodržive ekspanzije domaće potražnje i učiniti ekonomiju ranjivom na vanjske šokove. S obzirom na to da se šokovi pojavljuju iznenada, države s tržištima u nastajanju često kod izbijanja šokova budu uhvaćene nespremne. Vanjski šokovi mogu biti različitih vrsta, može, primjerice, biti riječ o naglim promjenama u globalnim monetarnim uvjetima, o padu povjerenja investitora ${ }^{4}$, nagloj korekciji cijena glavnih izvoznih dobara ili o tome da glavni vanjskotrgovinski partneri uvode protekcionističke mjere. ${ }^{5}$ Neovisno o kakvom je šoku riječ, vanjski šok u pravilu dovodi do

precijenjen, kreditni rast snažan te kada su kamatne stope u razvijenim gospodarstvima na uzlaznoj putanji. Većinu ovih činitelja kao ključne su izdvojili i Sachs, Tornell i Velasco (1996.).

${ }^{3}$ Ovaj se rizik često naziva valutno induciranim kreditnim rizikom zato što materijalizacija valutnog rizika za dužnika može izazvati materijalizaciju kreditnog rizika za vjerovnika.

${ }^{4}$ Pad povjerenja investitora može pogoditi jednu državu ili skupinu država koje dijele slična obilježja. Primjer šoka povjerenja s učinkom na više država istodobno bio je tzv. taper tantrum iz svibnja 2013. Tada je američki Sustav federalnih rezervi objavio da razmatra postupno gašenje svog programa nekonvencionalnih mjera monetarne politike što je potaknulo investitore da iznova razmotre visinu globalnih premija rizika. To se negativno odrazilo na nekoliko država s tržištima u nastajanju koje su u tom trenutku bile ranjive zbog povišenih makroekonomskih neravnoteža (Sahay i sur., 2014.).

${ }^{5}$ Primjerice, u studenom 2016. meksički peso snažno je deprecirao u odnosu na američki dolar nakon pobjede Donalda Trumpa na predsjedničkim izborima u SAD-u jer su investitori strahovali da će novi predsjednik ispuniti 
pogoršanja pristupa inozemnim izvorima financiranja za države s tržištima u nastajanju. Najpoznatiji primjeri su financijske krize u državama Latinske Amerike tijekom 1980-ih i 1990-ih.

Dužnička kriza u Latinskoj Americi početkom 1980-ih bila je posljedica nekontroliranog zaduživanja tijekom prethodnog desetljeća. Naime, tijekom 1970-ih, Argentina, Brazil i Meksiko značajno su se zaduživale u inozemstvu u američkim dolarima kako bi financirale svoje velike platnobilančne potrebe. Do kraja 1970-ih postalo je jasno da ubrzana akumulacija duga nije održiva i da je tim državama potrebna vanjska prilagodba (Federal Deposit Insurance Corporation, 1997.). Unatoč tome, inozemne banke, posebice one iz SAD-a, nastavile su intenzivno kreditirati tu regiju. Situacija se, međutim, dramatično promijenila početkom 1980-ih kada je američki Sustav federalnih rezervi (Fed) stegnuo monetarnu politiku kako bi obuzdao visoku inflaciju u SAD-u. Ta promjena vrlo je štetno djelovala na visokozadužene latinoameričke države. Ne samo da su porasle kamatne stope na njihove inozemne obveze, nego su im i nacionalne valute znatno oslabjele u odnosu na američki dolar, što je povećalo teret otplate visokog dolarskog duga. Premda je većina latinoameričkih država nastavila otplaćivati svoje inozemne obveze, težak teret otplate duga pridonio je dubokoj i dugotrajnoj recesiji koja se zadržala do kraja tog desetljeća.

Intenzivno zaduživanje države u stranoj valuti bilo je glavni uzročnik i financijske krize u Meksiku 1994. S obzirom na izražene makroekonomske neravnoteže i visoke potrebe za financiranjem koje je Meksiko tada imao, investitori su bili zabrinuti da u kontekstu pogoršanih globalnih monetarnih uvjeta meksičke vlasti neće moći zaštititi svoju valutu, peso, od deprecijacije. Tu zabrinutost investitora dodatno je podgrijavala domaća politička nestabilnost koja je svoj vrhunac dosegnula koncem 1994., što je bilo okidač za bijeg kapitala iz zemlje (MMF, 2012.). Kriza likvidnosti ubrzo je prerasla u valutnu i dužničku krizu, pa su meksičke vlasti bile primorane zatražiti financijsku pomoć SAD-a i MMF-a.

Ranjivost na povremene dužničke i valutne krize nije obilježje samo moderne globalizirane ekonomije koju karakteriziraju fleksibilni devizni tečajevi i intenzivni prekogranični tokovi kapitala. To se događalo s vremena na vrijeme tijekom povijesti čak i kada se cijeli svijet oslanjao na fiksne tečajeve i kada su bruto kapitalni tokovi bili znatno manji. Ovdje vrijedi spomenuti dužničku krizu u Njemačkoj početkom 1930-ih. Njemačka se do sredine 1920-ih vratila zlatnom standardu nakon čega se snažno zaduživala u stranoj valuti, uglavnom kako bi pribavila zlato i konvertibilne valute potrebne za podmirivanje velikih ratnih reparacija nakon poraza u Prvome svjetskom ratu (Ritschl, 2013.). U 1929. objavljen je revidirani, mnogo zahtjevniji plan otplate reparacija, što je izazvalo zabrinutost investitora, pa je Njemačka izgubila pristup inozemnom financiranju. Izbijanje Velike depresije dodatno je pogoršalo već ionako vrlo tešku situaciju. Suočena s visokim potrebama za refinanciranjem i ubrzanim trošenjem međunarodnih pričuva, njemačka središnja banka je 1931. odlučila uvesti kapitalne kontrole. Konačno, 1933. Njemačka je objavila da prestaje otplaćivati većinu svojih inozemnih obveza. 


\subsubsection{Smanjena sposobnost interveniranja u slučaju financijske krize}

Opisane epizode dužničkih kriza pokazuju kako prekomjerno zaduživanje u stranoj valuti može učiniti države ranjivima na „samoispunjavajuća proročanstva“. ${ }^{6}$ Osjetljivost na nagle promjene u pouzdanju investitora proizlazi iz nemogućnosti države da samostalno kreira stranu valutu potrebnu za otplatu obveza ako mnogi od investitora istodobno odluče povući svoja sredstva. S druge strane, države koje se mogu zaduživati isključivo u vlastitoj valuti nemaju takvih problema.

Premda zaduživanje u domaćoj valuti ne otklanja u potpunosti rizik dužničke krize, ono posredno državi omogućuje da se lakše nosi s krizom ako se ona zaista pojavi. Konkretno, ako se i država i privatni sektor pretežno zadužuju u domaćoj valuti, središnja banka neće morati toliko brinuti o fluktuacijama deviznog tečaja, pa će u razdobljima krize moći slobodnije kreditirati banke kako bi ublažila poremećaje likvidnosti. Ti se poremećaji često pojavljuju kod krize državnog duga jer deponenti u takvim uvjetima postaju zabrinuti oko mogućeg negativnog učinka dužničke krize na solventnost banaka. Djelujući kao zajmodavac u krajnjoj nuždi središnja banka opskrbljuje zdrave banke dodatnom likvidnošću potrebnom da podmire povećane zahtjeve za isplatom depozita. To ne samo da pomaže ublažiti probleme likvidnosti u bankovnom sustavu nego i posredno omogućuje državi da refinancira svoje obveze kod banaka po povoljnim uvjetima.

Europska dužnička kriza čija se akutna faza odvijala u razdoblju od 2010.-2012. zorno je pokazala da monetarne operacije središnje banke mogu imati ključnu ulogu u ublažavanju posljedica financijske krize. Na vrhuncu dužničke krize, Eurosustav - kojega čine Europska središnja banka (ESB) i nacionalne središnje banke iz eurozone - odobrio je znatne iznose sredstava grčkim, irskim, portugalskim i španjolskim bankama koje su do tada u potpunosti izgubile pristup tržišnom financiranju (Grafikon 2.). Nema sumnje da bi dužnička kriza bila mnogo teža da Eurosustav nije intervenirao s ciljem sprječavanja potpunog kolapsa bankovnih sustava rubnih članica eurozone. Osim pružanja likvidnosti bankama, čime se posredno pomoglo ranjivim državama da pribave prijeko potrebno financiranje, Eurosustav je poduzeo i niz mjera za izravno saniranje poremećaja na tržištu javnog duga. ${ }^{7}$

Nakon izbijanja pandemije virusa COVID-19 početkom 2020. ponovno se očitovalo da ESB posjeduje gotovo neograničen kapacitet upravljanja krizom. U vrijeme dok države članice nisu uspijevale postići dogovor o zajedničkom fiskalnom odgovoru na krizu, ESB je već sredinom ožujka 2020. preuzeo inicijativu najavivši provedbu PEPP-a (Pandemic Emergency Purchase Programme) vrijednog 750 milijardi eura. ${ }^{8} \mathrm{U}$ okviru ovog programa ESB svakog mjeseca kupuje velike količine vrijednosnica javnog i privatnog sektora kako bi spriječio rast cijene zaduživanja. Takva intervencija ESB-a bila je ključna tijekom kritične faze krize jer je ublažila

\footnotetext{
${ }^{6}$ Postoji opsežna literatura koja se bavi problemom ranjivosti država s tržištima u nastajanju na samoispunjavajuće panike (Obstfeld, 1986.; Obstfeld, 1994.; Eichengreen, Rose i Wyplosz, 1995.; Flood i Marion, 1996.; Cole i Kehoe, 2000.).

7 Za pregled nekonvencionalnih mjera ESB-a, vidi Constancio (2012.), Gros, Alcidi i Giovanni (2012.) i Micossi (2015.).

8 U lipnju 2020. ESB je odlučio povećati kapacitet programa sa 750 na 1.350 mlrd eura.
} 
pritiske na države koje su bile posebno jako pogođene pandemijom i tako njihovim vladama omogućila da financiraju zdravstvene izdatke i programe potpore gospodarstvu po niskim kamatnim stopama. Središnje banke ostalih razvijenih država poduzele su slične mjere kao odgovor na krizu.

\section{Grafikon 2.}

Zaduživanje kod Eurosustava kao postotak ukupnih obveza banaka

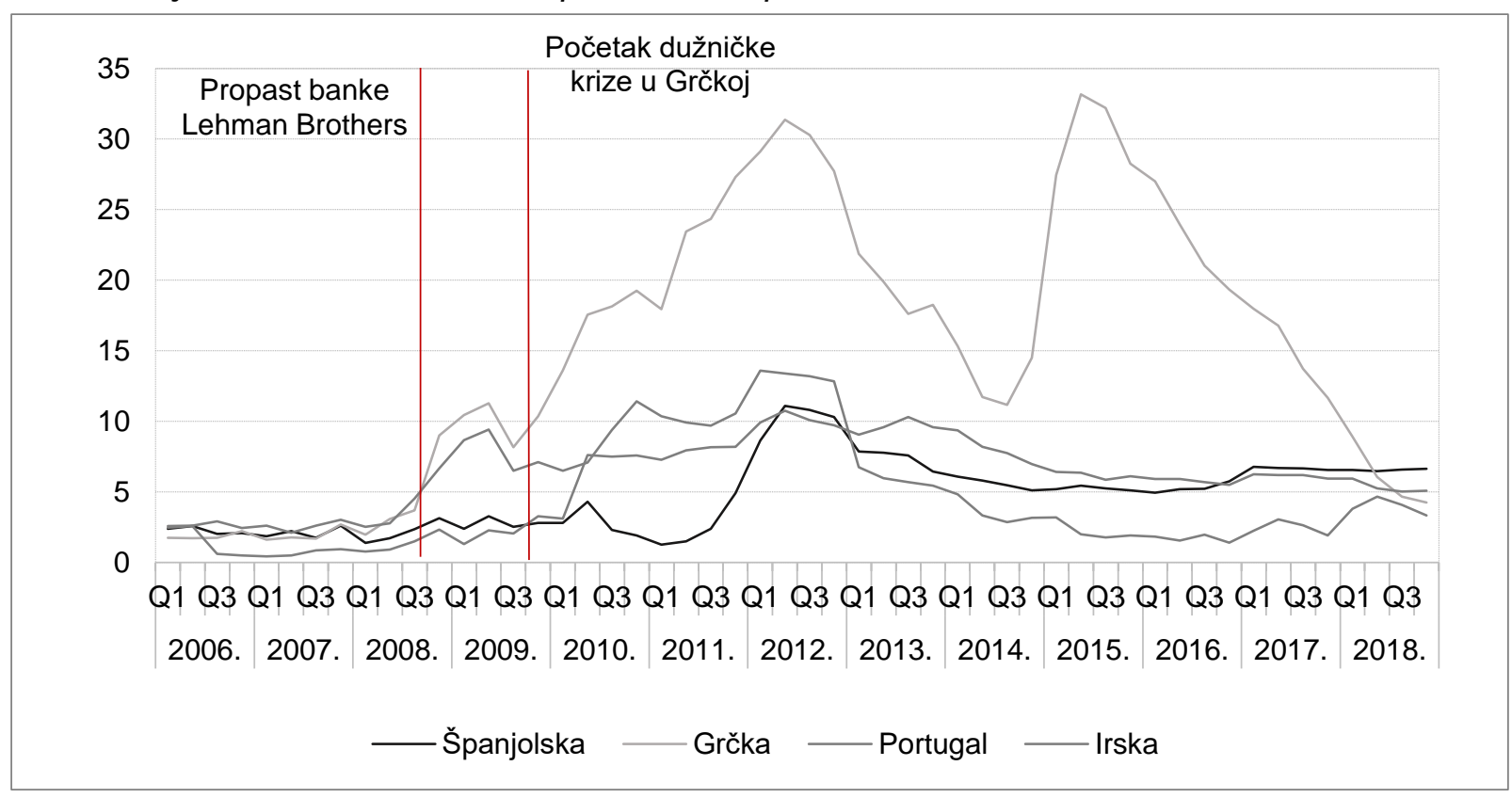

Izvori: ESB SDW; izračun autora

Kapacitet središnje banke da suzbija financijske krize mnogo je manji u državama u kojima su obveze javnog i privatnog sektora pretežno nominirane u stranoj valuti. Postoje barem tri razloga zbog kojih je to tako. Prvi, središnja banka ne može znatnije pomoći državi suočenoj s poteškoćama pri refinanciranju jer središnja banka može tiskati samo domaću, a ne i stranu valutu koja je državi potrebna za otplatu duga. ${ }^{9}$ Drugi, nemogućnost središnje banke da u punom smislu djeluje kao zajmodavac u krajnjoj nuždi ako je pasiva banaka dolarizirana (euroizirana). Naime, ako su obveze banaka (depoziti i primljeni krediti), većinom nominirani u stranoj valuti, središnja banka plasiranjem sredstava u domaćoj valuti neće uspjeti primiriti poremećaje likvidnosti u bankovnom sustavu. Ono što banke trebaju u takvim situacijama je strana valuta. ${ }^{10}$ Treći, u slučaju preambiciozne monetarne intervencije, postoji opasnost od

\footnotetext{
${ }^{9}$ Kapacitet središnje banke da podupire javni dug u stranoj valuti ograničen je razinom njezinih međunarodnih pričuva. S druge strane, kapacitet za interveniranje na tržištima financiranja u domaćoj valuti nije izravno određen razinom pričuva. Na vrhuncu krize izazvane pandemijom virusa COVID-19 središnje banke većeg broja država s tržištima u nastajanju poduzele su nekonvencionalne monetarne politike za podupiranje gospodarstva, uključujući otkup državnih vrijednosnica u domaćoj valuti (MMF, 2020.). Međutim, da bi takvi programi bili vjerodostojni, središnja banka treba imati dostatnu razinu međunarodnih pričuva jer to pomaže umiriti financijska tržišta da novokreirani novac neće izazvati deprecijaciju valute.

${ }^{10}$ Središnja banka će u takvim okolnostima najprije smanjiti obveznu pričuvu kako bi bankama otpustila njihove vlastite zalihe devizne likvidnosti. Ako se pokaže da su te zalihe nedostatne, središnja banka može odlučiti prodati bankama dio svojih međunarodnih pričuva putem deviznih intervencija ili ugovora o zamjeni. Sposobnost središnje banke da plasira deviznu likvidnost na ovaj način je dakako ograničena visinom raspoloživih međunarodnih pričuva (Chang i Velasco, 1998.).
} 
deprecijacije tečaja. Drugim riječima, u dolariziranim državama bilo bi rizično kada bi središnja banka otkupljivala velike količine državnih obveznica ili plasirala bankama obilne iznose u domaćoj valuti jer bi to moglo potaknuti špekulacije protiv valute i dovesti do štetne deprecijacije tečaja.

Dakle, u visoko dolariziranim državama kapacitet središnje banke da djeluje kao zajmodavac u krajnjoj nuždi značajno je manji, pa je time i slabija sposobnost tih država da samostalno saniraju bankovne i dužničke krize. U tom smislu, ovisnost o zaduživanju u stranoj valuti može se smatrati „prokletstvom“ jer ono povećava vjerojatnost da država doživi financijsku krizu i istodobno ju čini manje sposobnom da upravlja krizom ako se ona zaista dogodi.

\subsection{KORISTI ZADUŽIVANJA U STRANOJ VALUTI}

\subsubsection{Niži trošak financiranja}

Valutni rizik ne postoji, a rizik refinanciranja obično je niži kada su dugovi nominirani u domaćoj valuti. Postavlja se onda pitanje zašto se neki subjekti zadužuju u stranoj kada je zaduživanje u domaćoj valuti mnogo manje rizično. Glavni je razlog to što je financiranje u najvažnijim svjetskim valutama, kao što su američki dolar i euro, uglavnom jeftinije i izdašnije, pogotovo za mala otvorena gospodarstva. Preciznije, u državi s relativno malim domaćim financijskim sustavom lokalna ponuda možda neće biti dovoljna da zadovolji ukupnu potražnju za kreditima po povoljnim uvjetima. To može potaknuti državu i druge sektore da potraže jeftinije izvore financiranja u inozemstvu, bilo izravno - uzimanjem kredita kod stranih banaka i izdavanjem obveznica na međunarodnim tržištima - ili neizravno - zaduživanjem kod lokalnih banaka koje uvoze kapital iz inozemstva za financiranje kreditne aktivnosti u zemlji. Budući da se samo nekolicina država u svijetu može u inozemstvu zaduživati u svojoj vlastitoj valuti, inozemno zaduživanje u većini slučajeva vodi povećanoj izloženosti valutnom riziku.

Nadalje, čak i kada se država zadužuje na domaćem tržištu, ti dugovi su često vezani uz stranu valutu. Kako objašnjavaju Claessens, Schmukler i Klingebiel (2007.), male države obično imaju relativno mali broj lokalnih investitora pa se zato odlučuju na izdavanje vrijednosnica vezanih uz jednu od glavnih svjetskih valuta kako bi potaknule interes stranih investitora. Dodatna potražnja koju stvaraju strani investitori može osigurati veću dostupnost i niži trošak financiranja za državu.

Zaduživanje u stranoj valuti može potaknuti investicije i ekonomski razvitak uz uvjet da je za državu jeftinije i da su posuđena sredstva usmjerena u produktivne sektore. Konkretno, vlada neke slabo razvijene države može se zadužiti u inozemstvu za financiranje produktivnih investicija, kao što su veliki infrastrukturni projekti, koji mogu stvoriti preduvjete za brži rast u budućnosti. Uvozom dodatnog kapitala iz inozemstva, država ublažava pritiske na oskudne lokalne izvore financiranja kako ne bi došlo do istiskivanja privatnih investicija. Nositelji ekonomskih politika moraju se pobrinuti da se sredstva posuđena u inozemstvu ne pretoče u prekomjernu domaću potrošnju koja bi mogla rezultirati pregrijavanjem gospodarstva. Kada se uzme u obzir velik broj financijskih kriza nastalih zbog prekomjernog inozemnog zaduživanja i potrošnje, može se ustvrditi da države s tržištima u nastajanju nisu osobito uspješne u upravljanju tokovima kapitala. Primjerice, Kaminsky, Reinhart i Végh (2005.) pronašli su da u državama s tržištima u nastajanju postoji pozitivna korelacija između obujma neto kapitalnih 
priljeva i razine državne potrošnje, što upućuje na to je fiskalna politika u pravilu prociklična tijekom financijskog ciklusa.

\subsubsection{Doprinos financijskoj stabilnosti u visoko euroiziranim (dolariziranim) državama}

U određenim okolnostima zaduživanje u stranoj valuti može biti i neophodno za očuvanje financijske stabilnosti. Naime, ako je država visoko zadužena u stranoj valuti, vrlo je važno da zadrži pristup financiranju u stranoj valuti kako bi mogla refinancirati dospjele obveze bez iscrpljivanja međunarodnih pričuva. U slučaju da država taj pristup izgubi, bila bi prisiljena kupovati stranu valutu na domaćem tržištu kako bi podmirila svoje obveze, što bi moglo destabilizirati valutu i naposljetku dovesti do devalvacije. Ranije spomenute epizode financijskih kriza nesumnjivo govore u prilog ovoj tvrdnji.

Također, zaduživanje države u stranoj valuti može pozitivno utjecati na financijsku stabilnost ako je bankovni sustav visoko euroiziran (dolariziran). Jedan od glavnih problema koji proizlaze iz euroizacije je to što središnje banke takvih država ne mogu u punom smislu djelovati kao zajmodavci u krajnjoj nuždi (Chang i Velasco, 2002.). Naime, ako su obveze poslovnih banaka nominirane u stranoj valuti, u slučaju da se banke suoče s krizom likvidnosti središnja banka im ne može pomoći „tiskanjem“ domaće valute. U takvim uvjetima, kapacitet središnje banke da djeluje u svojstvu zajmodavca u krajnjoj nuždi ovisit će o visini njezinih međunarodnih pričuva: što su pričuve više, veći će biti kapacitet središnje banke da intervenira. ${ }^{11}$ Stoga, priljev deviza zaduživanjem države u stranoj valuti može imati blagotvoran utjecaj jer omogućuje središnjoj banci da akumulira međunarodne pričuve koje kasnije mogu biti upotrijebljene za suzbijanje poremećaja likvidnosti u bankovnom sustavu.

Zaduživanje države kao izvor akumulacije međunarodnih pričuva osobito je važno u državama poput Hrvatske, u kojima je problem euroizacije (dolarizacije) uvelike interno kreiran, umjesto da je odraz inozemnog zaduživanja banaka. Konkretno, u nekim državama građani imaju snažnu sklonost držanju štednih depozita u važnim svjetskim valutama, kao što su euro ili američki dolar, iako većina njih ne ostvaruje nikakve prihode u tim valutama. Dakle, tehnički gledano, deponenti donose u banku domaću valutu i polažu je na devizne depozite čime stječu potraživanje prema banci u stranoj valuti. Gledano iz perspektive banke, iako deponent nije donio stranu valutu u banku, banka je u svojoj pasivi zabilježila povećanje obveza u stranoj valuti. Kako bi se zaštitila od utjecaja fluktuacija deviznog tečaja, banka će vjerojatno i svoje plasmane odobravati u stranoj valuti, čime će valutni rizik prenijeti na svoje dužnike. U takvim okolnostima, središnja banka će nastojati akumulirati dovoljne količine međunarodnih pričuva kako bi bila sposobna po potrebi braniti stabilnost valute, a najjednostavniji način da to učini je tako da otkupljuje stranu valutu koju je vlada donijela u zemlju zaduživanjem u inozemstvu.

\footnotetext{
${ }^{11}$ Međutim, u slučaju snažne bankovne krize čak i izdašne međunarodne pričuve mogu se pokazati nedostatnima za istodobno smirivanje bankovne krize i podupiranje valute. Ovdje vrijedi spomenuti primjer latvijske krize 2008 ., kada je dramatičan odljev deviznih depozita iz jedne velike banke rezultirao ubrzanim iscrpljivanjem međunarodnih pričuva središnje banke te tako umanjio vjerodostojnost politike fiksnog tečaja prema euru. Ti poremećaji potaknuli su latvijske vlasti da zatraže međunarodnu financijsku pomoć (Purfield i Rosenberg, 2010.; MMF, 2009.).
} 


\section{Grafikon 3.}

Zaduživanje države u stranoj valuti i akumulacija pričuva u Hrvatskoj

a) Međunarodne pričuve i neto otkup deviza od banaka i Ministarstva financija, u mlrd eura b) Doprinosi kumulativnom povećanju međunarodnih pričuva u razdoblju 2002.-2019.

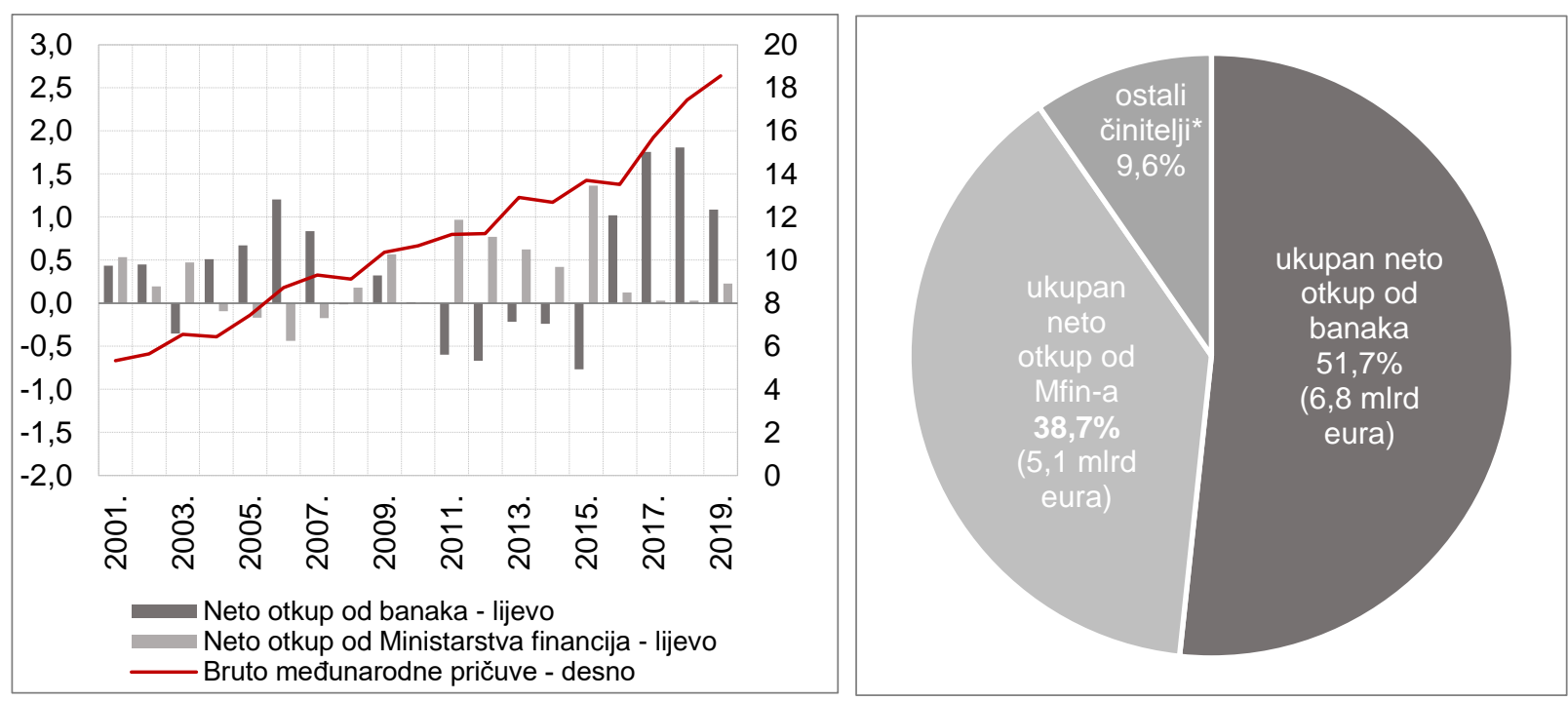

Napomena: *Ostali činitelji odnose se na promjene deviznog tečaja i transakcije s proračunom EU-a Izvori: HNB; izračun autora

Grafikon 3. pokazuje da je zaduživanje države značajno doprinijelo akumulaciji pričuva u Hrvatskoj tijekom posljednja dva desetljeća. U razdoblju od 2001.-2019. pričuve HNB-a ukupno su porasle za 13,2 mlrd eura (s 5,3 na 18,6 mlrd), pri čemu se od ukupnog povećanja na konačni otkup deviza od Ministarstva financija odnosilo $5,1 \mathrm{mlrd}(38,7 \%)$. Dakako, zaduživanje države posebice je pridonijelo rastu pričuva u razdoblju nakon svjetske financijske krize kada je Hrvatska izdavala znatne količine obveznica u stranoj valuti za financiranje ustrajno visokih proračunskih manjkova (HNB, 2012.). Međutim, s obzirom na to da je proračunski manjak postupno prešao u višak, od 2016.-2019. država je samo refinancirala postojeće obveze u stranoj valuti koje su dospijevale, a da pritom nije preuzimala dodatan dug. Posljedično, neto otkup deviza od Ministarstva financija znatno se smanjio. To se, međutim, promijenilo 2020. kada je povećana fiskalna potrošnja u svrhu ublažavanja negativnih ekonomskih posljedica pandemije virusa COVID-19 iziskivala pribavljanje dodatnih sredstava iz inozemstva (HNB, 2020.).

Naposljetku, dodatna, manje značajna korist zaduživanja države u stranoj valuti je što središnja banka devizna sredstva koju država pribavi zaduživanjem usmjerava u inozemnu imovinu koja posredno generira prihode za državni proračun. Naime, ako se država zadužuje u stranoj valuti kako bi financirala fiskalne izdatke u zemlji, devizna sredstva pribavljena zaduživanjem države bit će zamijenjena kod središnje banke za domaću valutu. Središnja banka nadalje ulaže ta devizna sredstva u visokokvalitetnu inozemnu imovinu, kao što su nerizične državne obveznice i depoziti u inozemnim bankama. U normalnim okolnostima takva imovina nosi pozitivnu kamatnu stopu pa će središnja banka na njoj ostvariti određenu 
zaradu. ${ }^{12}$ Budući da većina središnjih banaka - nakon što podmiri svoje operativne rashode većinu svojih prihoda uplaćuje u državni proračun, država će posredno ostvariti određene prihode od imovine koju je središnja banka stekla na opisani način. Zahvaljujući tome, trošak otplate inozemnog duga za državu će biti efektivno niži. ${ }^{13}$

Treba istaknuti da zaduživanje države u stranoj valuti ne može beskonačno služiti kao izvor akumulacije međunarodnih pričuva. $U$ jednom trenutku omjer javnog duga i BDP-a mora se stabilizirati jer će u suprotnome održivost duga doći u pitanje. U takvim uvjetima, država će samo refinancirati postojeće obveze u stranoj valuti ili će ih čak otplaćivati kako bi smanjila svoju izloženost valutnom riziku. Smanjenje duga u stranoj valuti razborito je i poželjno ako se provodi u povoljnim makroekonomskim prilikama kada je platno-bilančna pozicija države snažna, kao što je bio slučaj u Hrvatskoj posljednjih nekoliko godina. Kako se opisuje kasnije u ovom radu, ustrajni viškovi na tekućem računu platne bilance i izdašna likvidnost $u$ domaćem financijskom sustavu omogućili su Vladi da donekle poboljša valutnu strukturu javnog duga, a da pritom ne dođe do iscrpljivanja međunarodnih pričuva.

\section{KAKO DRŽAVA KOJA SE ZADUŽUJE U STRANOJ VALUTI MOŽE SMANJITI RIZIK DUŽNIČKE KRIZE?}

Kao što je spomenuto u prethodnom poglavlju, zaduživanje u stranoj valuti može državu jače izložiti dužničkim i valutnim krizama. Mehanizam koji se aktivira tijekom dužničkih kriza sličan je onome koji je na snazi tijekom „navala na banke“. Diamond i Dybvig (1983.) definiraju navalu na banke kao nepoželjan ravnotežni ishod u sustavu u kojemu se banke pretežno financiraju kratkoročnim depozitima. Ako se povjerenje štediša u određenu banku uruši, pa počnu naveliko povlačiti depozite, banka će imati poteškoća s isplatom njihovih depozita jer gotov novac čini samo mali dio ukupne imovine banke. Naposljetku, banka će biti prisiljena prodati dio svoje manje likvidne imovine uz gubitak, što ju može dovesti do insolventnosti. Sličan slijed događaja dovodi do krize javnog duga: ako držatelji obveznica postanu nesigurni može li država nastaviti otplaćivati svoj dug, država će biti prisiljena otplaćivati glavnice kako dospijevaju, što je teško ostvariti ako je pristup financiranju otežan.

Nekoliko osigurača se pokazalo učinkovitima u sprječavanju navala na banke, kao što su prudencijalna regulativa i supervizija, državna jamstva za male depozite i krediti središnje banke u svojstvu zajmodavca u krajnjoj nuždi. Ublažavanje rizika dužničke krize kada je država zadužena u stranoj valuti još je zahtjevniji zadatak od ublažavanje rizika u bankovnom sustavu. Osnovni pristup je, međutim, sličan: ključno je osigurati dostatne zalihe likvidnosti - u obliku izdašnih međunarodnih pričuva - te imati snažne makro-financijske pokazatelje.

\footnotetext{
12 Postoje, naravno, i drugi izvori prihoda za središnju banku osim prihoda od upravljanja međunarodnim pričuvama. Primjerice, središnje banke obično poslovnim bankama naplaćuju pozitivnu kamatnu stopu na repo zajmove odobrene u okviru redovnih monetarnih operacija. Nadalje, središnja banka otkupom državnih obveznica može ostvariti kamatni prihod na obveznicama pribavljenima na taj način. Taj kamatni prihod će, međutim, u kasnijoj fazi biti uplaćen u državni proračun u sklopu redovne raspodjele dobiti središnje banke.

${ }^{13} \mathrm{Na}$ primjer, ako država na međunarodnom tržištu emitira obveznicu uz kuponsku stopu od 4\%, a središnja banka ostvaruje prinos od 1,5\% na inozemnoj imovini koju je stekla nakon konverzije deviznih sredstava koja je država prikupila zaduživanjem, efektivna kamatna stopa koju država plaća na obveznicu iznosit će 2,5\% (uz pretpostavku da se dobit središnje banke u cijelosti uplaćuje u državni proračun).
} 


\subsection{ULOGA MEĐUNARODNIH PRIČUVA}

Prednosti držanja visokih međunarodnih pričuva višestruke su (Ljubaj, 2019.). Ako su dovoljno visoke, pričuve štite valutu od prekomjernih fluktuacija i špekulativnih napada, jamče sposobnost države da izvršava međunarodne transakcije u konvertibilnim valutama te tako jačaju vjerodostojnost države na financijskim tržištima. Zbog toga je vjerojatnost valutne krize u pravilu manja kada su pričuve visoke. ${ }^{14}$

Održavanje izdašnih međunarodnih pričuva posebice je važno ako je država snažno zadužena u stranoj valuti. Naime, visoka razina pričuva pruža jamstvo investitorima da će država biti sposobna podmirivati svoje obveze u stranoj valuti čak i ako privremeno izgubi pristup financijskim tržištima. Kao što je spomenuto ranije, u dolariziranom financijskom sustavu, međunarodne pričuve imaju dodatnu važnu ulogu jer omogućuju središnjoj banci da pomaže bankama u slučaju likvidnosnih poremećaja.

\section{Grafikon 4.}

Struktura imovine središnje banke, kraj 2018. (u \%)

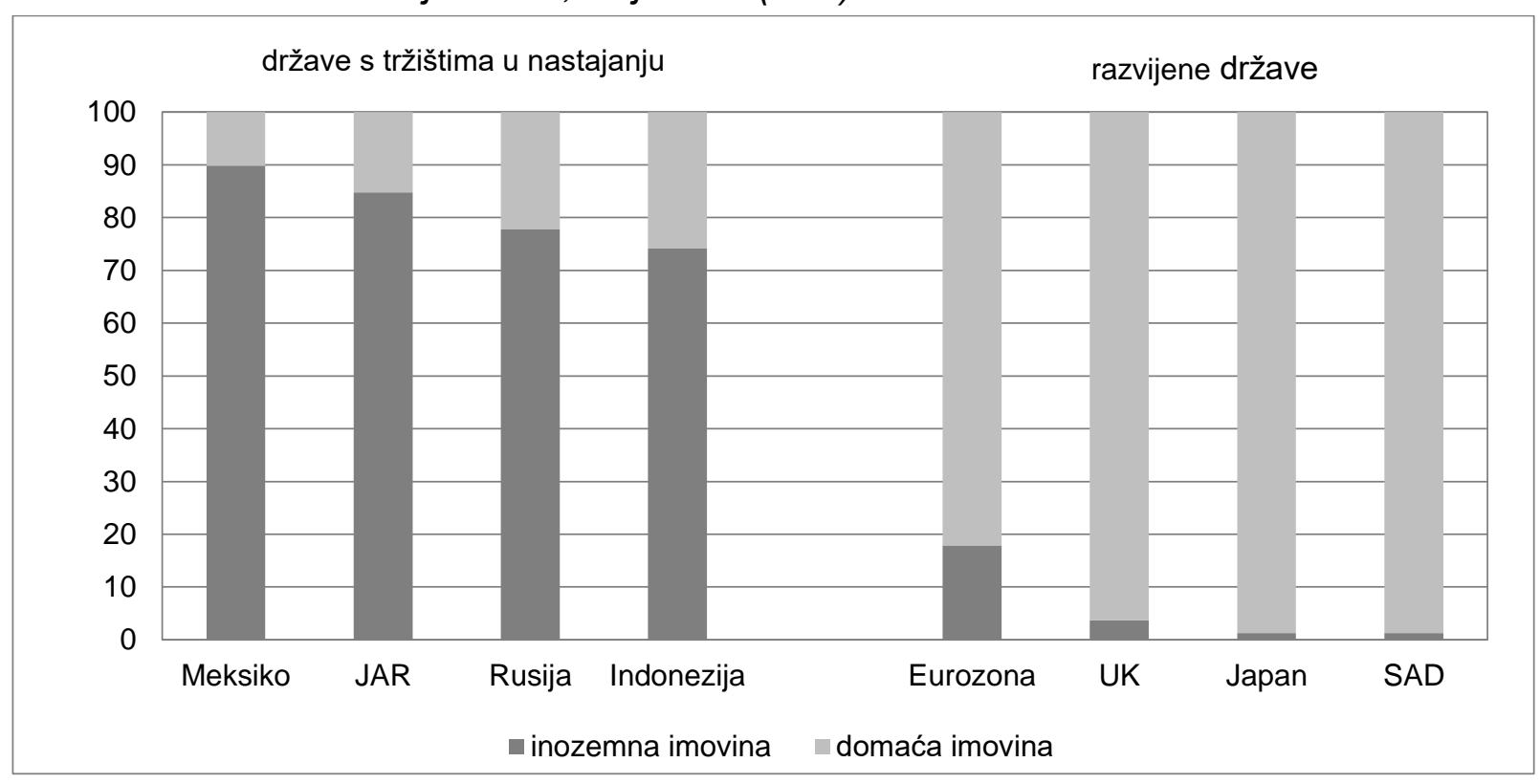

Izvor: IMF (2020b)

Hausmann, Panizza i Stein (2001.) pronalaze da države s tržištima u nastajanju, koje se u inozemstvu zadužuju pretežno u stranoj valuti, više strahuju od volatilnosti deviznog tečaja nego razvijene države. Zbog toga, države s tržištima u nastajanju u pravilu drže relativno veće zalihe međunarodnih pričuva koje im omogućuju da interveniraju na deviznom tržištu ako se pojave pritisci na valutu. Podaci snažno podupiru tvrdnje ovih autora. Grafikon 4. prikazuje strukturu imovine središnjih banaka četiri velike razvijene države i četiri velike države s tržištima u nastajanju. Nesumnjivo je da između ove dvije skupine država postoji velika razlika u relativnim udjelima inozemne imovine u ukupnoj imovini središnje banke. Dok u državama s

\footnotetext{
14 Većina radova o valutnim krizama ukazuje da je nedostatnost pričuva jedan od najboljih ranih pokazatelja valutnih kriza (Kaminsky, Lizondo i Reinhart, 1998.; Kruger, Osakwe i Page, 1998.; Vlaar, 2000.; Abiad, 2003.; Babecky i sur., 2012.).
} 
tržištima u nastajanju inozemna imovina predstavlja više od tri četvrtine ukupne imovine središnje banke, kod razvijenih država taj je udio u pravilu vrlo nizak.

\subsection{ULOGA OSTALIH MAKRO-FINANCIJSKIH FUNDAMENATA}

Najučinkovitiji instrument za sprječavanje krize javnog duga je, dakako, razborita fiskalna politika. Održavanjem uravnoteženog proračunskog salda i dovoljno niskog omjera duga i BDP-a, država minimizira rizik iznenadnog gubitka pristupa financiranju. Suprotno tome, ako je proračunski manjak prekomjeran, a javni dug je visok i brzo se povećava, investitori će imati razloga brinuti o održivosti duga te države. Treba, međutim, naglasiti da slabi fiskalni pokazatelji ne moraju nužno odmah dovesti do dužničke krize. Ako su globalni monetarni uvjeti povoljni i sklonost investitora riziku je visoka, država može određeno vrijeme uživati nesmetan pristup financiranju unatoč svojim slabim fiskalnim ostvarenjima. Međutim, zbog slabih makroekonomskih fundamenata, država će biti pojačano osjetljiva na „samoispunjavajuća proročanstva“, kao što je to zorno pokazao primjer dužničke krize u Grčkoj (Higgins i Klitgaard, 2014.).

Ročnost duga također je važna. ${ }^{15}$ Što je dulje prosječno dospijeće duga, država će se lakše nositi s naglim promjenama raspoloženja na tržištima. Naime, kada su rokovi otplate duga raspoređeni kroz dulje vremensko razdoblje, prolazni šok koji povećava prinose na dug države odrazit će se samo na obveze koje dospijevaju u razdoblju kada je utjecaj šoka prisutan, dok ostatak duga neće biti zahvaćen. Suprotno tome, ako je prosječno dospijeće javnog duga kratko, mnoge obveze morat će se refinancirati u nepovoljnim tržišnim uvjetima što može biti vrlo skupo, a u nekim slučajevima čak i nemoguće. U većini kriza spomenutih u prethodnom poglavlju ključan je problem bilo upravo prekomjerno oslanjanje države na kratkoročno inozemno financiranje.

Osim što treba voditi odgovornu fiskalnu politiku, velika pozornost treba biti posvećena monetarnoj politici i politikama koje se odnose na financijski sektor. Kao što je danas općeprihvaćeno, monetarna politika treba biti usredotočena na održavanje niske i stabilne inflacije. Održavanjem stope inflacije blizu stopa inflacije glavnih vanjskotrgovinskih partnera, središnja banka može spriječiti štetnu realnu aprecijaciju valute. Kada je riječ o politikama za financijski sektor, vlasti trebaju budno provoditi superviziju i aktivno koristiti mikro i makroprudencijalnu politiku, jer propusti u ovom području mogu imati negativne posljedice za javne financije. ${ }^{16}$ Makroprudencijalna politika postala je iznimno popularna u razdoblju nakon svjetske financijske krize (Dumičić, 2015.). Ne samo da pomaže povećati otpornost banaka uvođenjem različitih zaštitnih slojeva kapitala, nego i omogućuje vlastima da adresiraju opće makroekonomske rizike usporavanjem prekomjernog kreditnog rasta i onemogućavanjem banaka da se pretjerano oslanjaju na nestabilne inozemne izvore financiranja.

\footnotetext{
15 Značaj ročne strukture javnog duga jasno potvrđuje Meksička kriza iz 1994., izazvana naglim povlačenjem investitora iz kratkoročnih državnih vrijednosnica nominiranih u američkim dolarima koje su se nazivale tesobonos (Sachs, Tornell i Velasco, 1996.).

${ }^{16}$ Kao što su pokazale recentne krize u Islandu, Španjolskoj i Irskoj, čak i ako su fiskalni pokazatelji općenito povoljni, održivost duga može brzo doći u pitanje ako teški gubici u sistemski važnim bankama prisile vladu da provodi skupe programe dokapitalizacije kako bi izbjegla potpuni kolaps bankovnog sustava.
} 
Slabi makroekonomski pokazatelji mogu državu dovesti u dužničku krizu čak i ako je dug u potpunosti nominiran u domaćoj valuti. Ovdje vrijedi istaknuti primjer dužničke krize u eurozoni s vrhuncem u razdoblju od 2010.-2012. Sve države zahvaćene tom krizom prije toga su se zaduživale gotovo isključivo u eurima, svojoj domaćoj valuti, ali ta ih činjenica nije zaštitila od gubitka pristupa tržišnom financiranju nakon što je kriza eskalirala. Investitori više nisu bili voljni kreditirati rubne članice eurozone zbog izraženih slabosti koje su te države pokazivale u svojim javnim financijama ili bankovnim sustavima. U Grčkoj i Portugalu glavni izvor ranjivosti bio je brzorastući javni dug u uvjetima ustrajno visokih proračunskih manjkova. Irska i Španjolska su, s druge strane, snažno povećanje javnog duga doživjele ne zbog loše fiskalne politike nego zato što su se njihove vlade upustile u skupu dokapitalizaciju posrnulih banaka (Brkić, 2020.).

\section{JESU LI JAVNE FINANCIJE U EU-U IZLOŽENE VALUTNOM RIZIKU? 4.1. ZADUŽIVANJE U STRANOJ VALUTI DRŽAVA ČLANICA EU-A KOJE NISU DIO EUROZONE}

Neke države članice EU-a koje nisu dio eurozone zadužuju se intenzivno u stranoj valuti, pretežno u euru. To se ponajprije odnosi na države iz srednje i istočne Europe (SIE), koje imaju plitka lokalna financijska tržišta pa se stoga često oslanjaju na inozemne izvore financiranja. Suprotno tome, u sjevernim državama članicama - Danskoj i Švedskoj zaduživanje u stranoj valuti nije sistemski problem. U tim razvijenim državama u stranoj se valuti zadužuju uglavnom poduzeća orijentirana na izvoz koja se na taj način štite od rizika promjene tečaja, dok stanovništvo i sektor države u pravilu nemaju tu praksu. ${ }^{17}$

Grafikon 5. prikazuje valutnu strukturu javnog duga šest država članica EU-a iz SIE. Države iz ove skupine u prosjeku bilježe znatno više udjele duga u stranoj valuti u ukupnom dugu nego sjeverne države članice, ali i među njima postoje znatne razlike u tome koliko intenzivno se oslanjaju na financiranje u stranoj valuti. Dvije države, Bugarska i Hrvatska, ističu se s više od tri četvrtine javnog duga nominiranog u stranoj valuti ili vezanog uz stranu valutu. ${ }^{18}$ Osjetljivost javnih financija na fluktuacije deviznog tečaja visoka je i u Rumunjskoj, čiji je ukupan javni dug podjednako sastavljen od obveza u domaćoj i stranoj valuti. S druge pak strane, valutni rizik puno je manji razlog za zabrinutost u Poljskoj, Mađarskoj te, posebice, u Češkoj.

\footnotetext{
17 Krajem 2018. danska vlada nije imala nikakvih obveza u stranoj valuti (Danmarks Nationalbank, 2019.). Premda je otprilike jedna četvrtina javnog duga Švedske nominirana u stranoj valuti, otvorena devizna pozicija mnogo je niža jer je švedski državni ured za upravljanje dugom posljednjih godina kupio znatne iznose strane valute kako bi smanjio izloženost valutnom riziku (Swedish National Debt Office, 2019.).

${ }^{18}$ Bugarska se zadužuje gotovo isključivo u eurima, dok je mali dio (manje od 5\%) javnog duga Hrvatske nominiran u američkim dolarima. Međutim, s obzirom na to da Vlada koristi ugovore o valutnoj zamjeni EUR/USD kako bi se zaštitila od izloženosti američkom dolaru, hrvatske javne financije osjetljive su jedino na fluktuacije tečaja kune prema euru (Ministarstvo financija Republike Hrvatske, 2017.).
} 


\section{Grafikon 5.}

Valutna struktura javnog duga, 2018. (u \%)

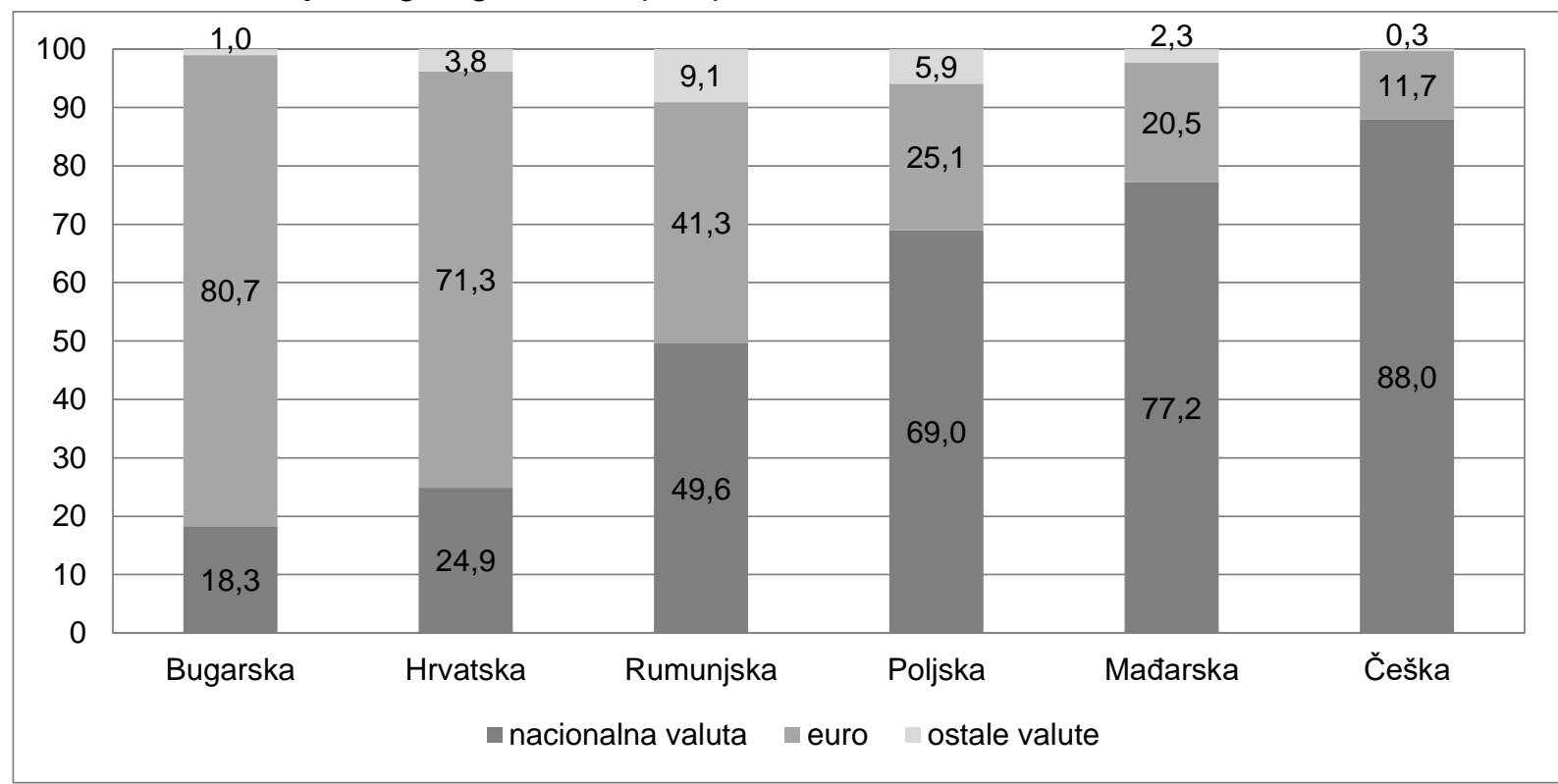

Izvor: Eurostat (2020a)

Zaduženost u stranoj valuti ne mora biti problematična za državu koja ima nesmetan pristup inozemnim tržištima i stabilnu valutu. Međutim, ako iz nekog razloga njezina valuta počne gubiti vrijednost u odnosu na valutu uz koju je javni dug vezan, država će zabilježiti povećanje omjera duga i BDP-a.

Grafikon 6. prikazuje jednostavnu simulaciju učinka deprecijacije tečaja na omjere javnog duga i BDP-a. Razumljivo, u slučaju deprecijacije, države čiji je javni dug u visokom postotku vezan uz stranu valutu, kao što su Bugarska i Hrvatska, doživjet će relativno snažnije pogoršanje omjera duga i BDP-a od država koje se manje oslanjaju na zaduživanje u stranoj valuti. Pri interpretaciji rezultata ove simulacije treba uzeti u obzir da se inicijalne razine javnog duga razlikuju među državama jer to utječe na iznos apsolutne promjene omjera duga i BDP-a nakon deprecijacije. Konkretno, iako Bugarska ima najviši udio duga u stranoj valuti u ovoj skupini država, zbog niske početne razine duga apsolutno povećanje omjera duga i BDP-a nakon deprecijacije nije veliko. U slučaju deprecijacije od $20 \%$ taj omjer bi kod Bugarske porastao za 3,6 postotnih bodova, što je samo neznatno više od vrijednosti za Rumunjsku i Mađarsku $(3,5$ odnosno 3,2$)$ te mnogo niže nego apsolutno povećanje za Hrvatsku $(11,2$ postotna boda). 
Grafikon 6.

Izloženost javnih financija valutnom riziku, 2018., u \% BDP-a

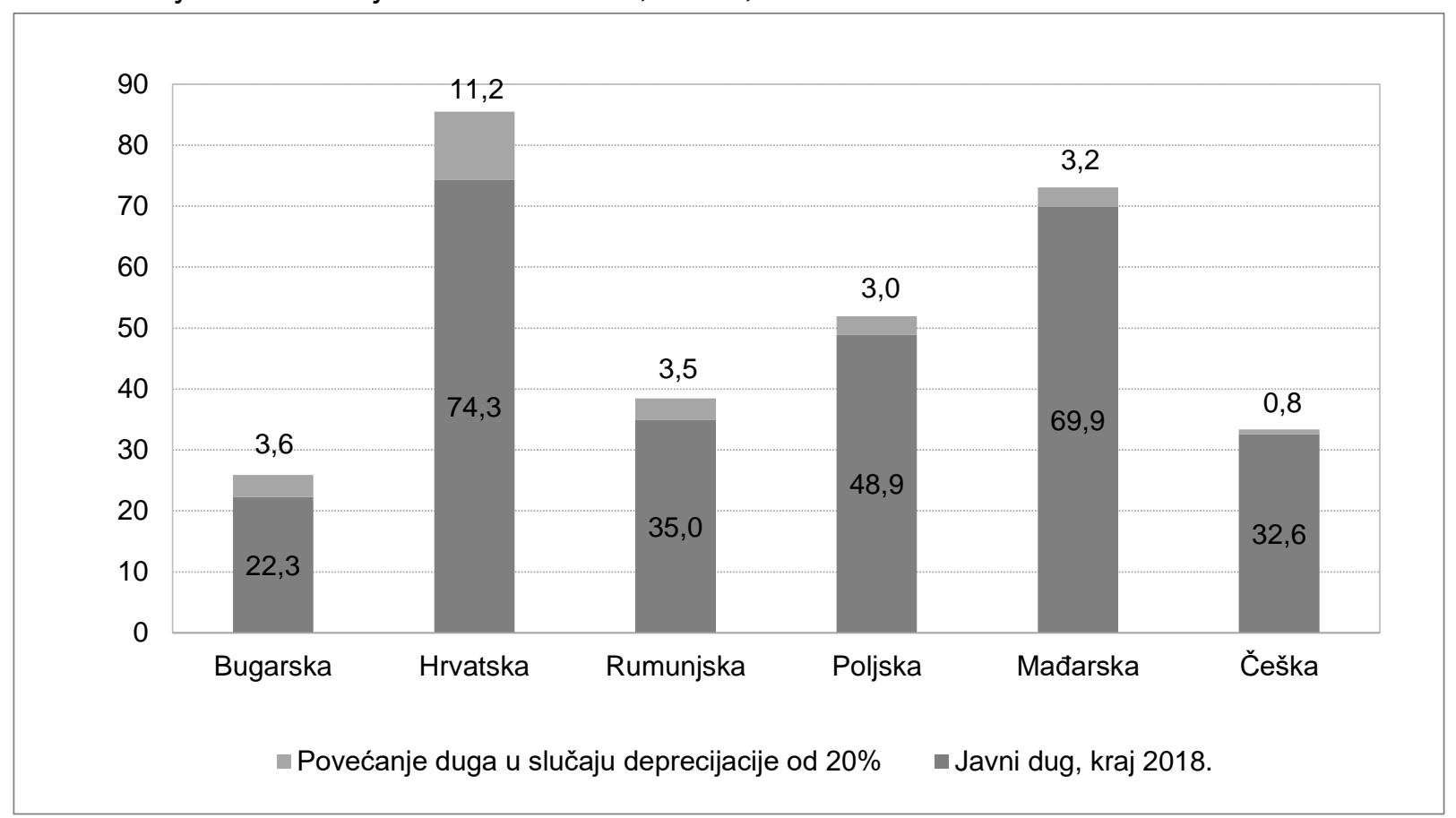

Izvori: Eurostat (2020a); izračun autora

Kao što pokazuje Grafikon 7., države koje se ističu vrlo visokim udjelom duga u stranoj valuti u ukupnom javnom dugu ujedno bilježe i najviši stupanj euroiziranosti bankovnog sustava. Konkretno, u Bugarskoj i Hrvatskoj depoziti u stranoj valuti čine znatan dio ukupnih obveza banaka, dok to, primjerice, nije slučaj u državama poput Poljske ili Češke. Povezanost valutne strukture javnog duga i stupnja euroizacije nije iznenađujuća s obzirom na to da su domaće banke u pravilu značajni investitori u instrumente javnog duga emitirane na domaćem tržištu. Naime, ako je velik dio njihovih obveza nominiran u stranoj valuti, banke će htjeti investirati u imovinu u stranoj valuti kako bi se zaštitile od valutnog rizika. S obzirom na važnost banaka kao investitora u javni dug, vlada će uzeti u obzir preferencije banaka kada će odlučivati o tome u kojoj će valuti izdati trezorske zapise ili obveznice. ${ }^{19}$ Zbog toga, u visoko euroiziranim državama udio duga u stranoj valuti u valutnoj strukturi javnog duga obično je viši od udjela nerezidenata u vlasničkoj strukturi duga. ${ }^{20}$ Drugim riječima, ne samo da je inozemna komponenta javnog duga vezana uz stranu valutu nego i velik dio domaće komponente duga.

\footnotetext{
${ }^{19}$ Osim ulaganja u dužničke instrumente u stranoj valuti izdane na lokalnom tržištu, domaće banke mogu kupovati i euroobveznice izdane na međunarodnim financijskim tržištima. Takva praksa prisutna je u Hrvatskoj.

${ }^{20}$ Konkretno, u Bugarskoj i Hrvatskoj dug u stranoj valuti čini $81 \%$, odnosno $72 \%$ ukupnog javnog duga, dok je udio duga koji drže nerezidenti znatno manji (44\%, odnosno 33\%). Nasuprot tome, u Poljskoj i Češkoj, koje su mnogo manje euroizirane, udio duga u stranoj valuti zapravo je niži od udjela duga koji drže nerezidenti $(28 \%$ i $11 \%$, u odnosu na $44 \%$ i $41 \%$ ), što upućuje na to da strani investitori drže nezanemarive iznose duga u domaćoj valuti koji izdaju ove dvije države.
} 
Grafikon 7.

Depoziti u stranoj valuti kod poslovnih banaka, 2018., u \%

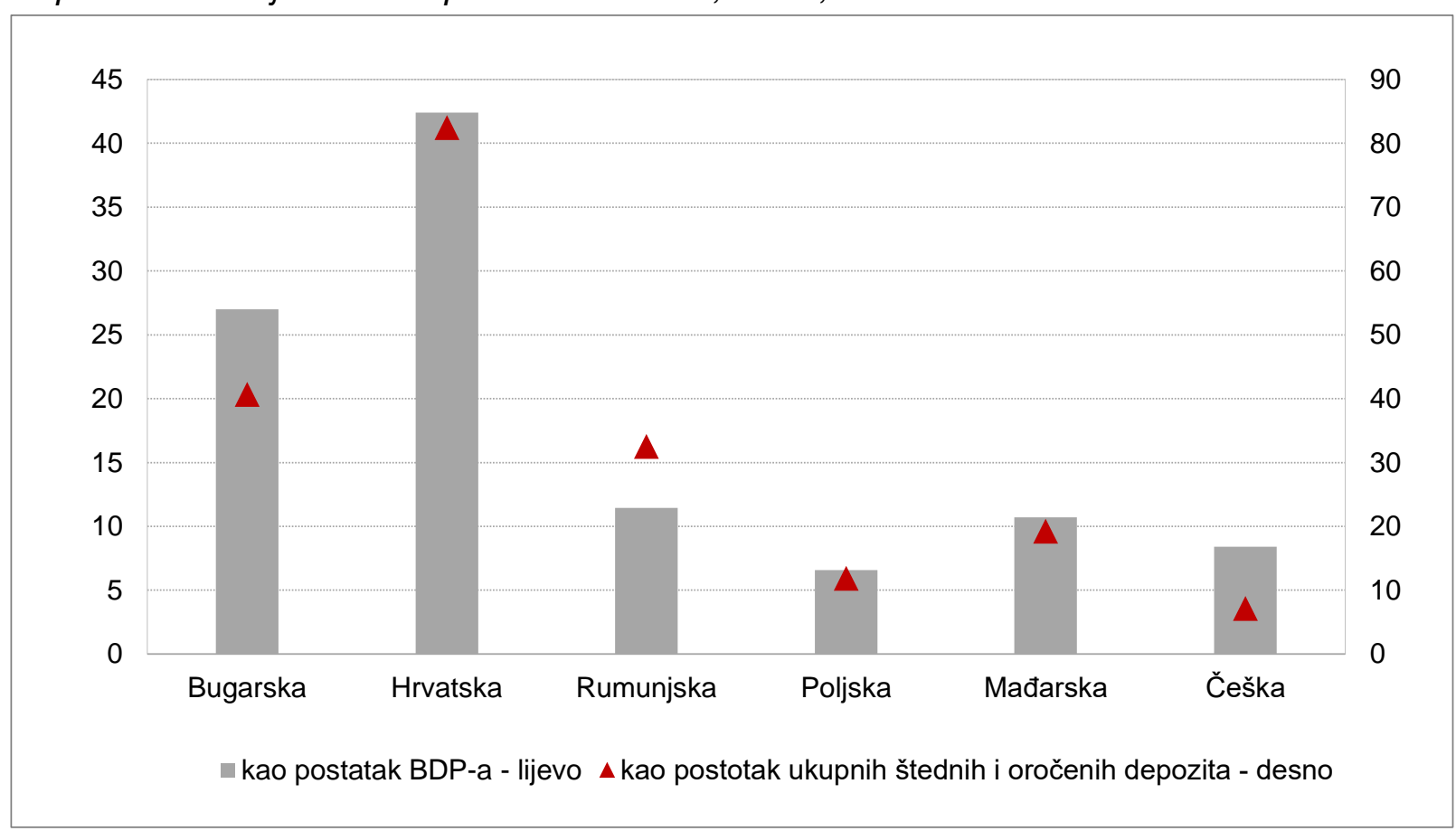

Izvori: Eurostat (2020b); nacionalne središnje banke; izračun autora

Kao što je navedeno u prethodnim poglavljima, visoki iznosi deviznih depozita prijetnja su financijskoj stabilnosti jer umanjuju sposobnost središnje banke da po potrebi djeluje u svojstvu zajmodavca u krajnjoj nuždi. Stoga, u visoko dolariziranim (euroiziranim) bankovnim sustavima ključno je da središnja banka drži izdašne međunarodne pričuve. Važnost pričuva još je veća ako uz dolarizaciju bankovnog sustava istodobno postoji i problem visokog javnog duga u stranoj valuti. Neke države SIE suočavaju se s oba problema istodobno. Grafikon 8. za svaku državu iz ove skupine uspoređuje razinu obveza u stranoj valuti - konkretno, prikazani su podaci za ukupan iznos deviznih depozita i podaci za javni dug vezan uz stranu valutu - s razinom međunarodnih pričuva. Grafikon sugerira da se države SIE međusobno znatno razlikuju po stupnju izloženosti valutnom riziku. Primjerice, Hrvatska i Bugarska bilježe najviše relativne iznose obveza u stranoj valuti, pri čemu one u Hrvatskoj znatno premašuju raspoloživi iznos međunarodnih pričuva. Nasuprot tome, Češka je posljednjih godina akumulirala iznimno visoke zalihe međunarodnih pričuva, uz istodobno nisku razinu obveza u stranoj valuti. Stoga se slobodno može da je Češka znatno manje osjetljiva na fluktuacije deviznog tečaja od Hrvatske i Bugarske. 
Grafikon 8.

Obveze u stranoj valuti i međunarodne pričuve, 2018., u \% BDP-a

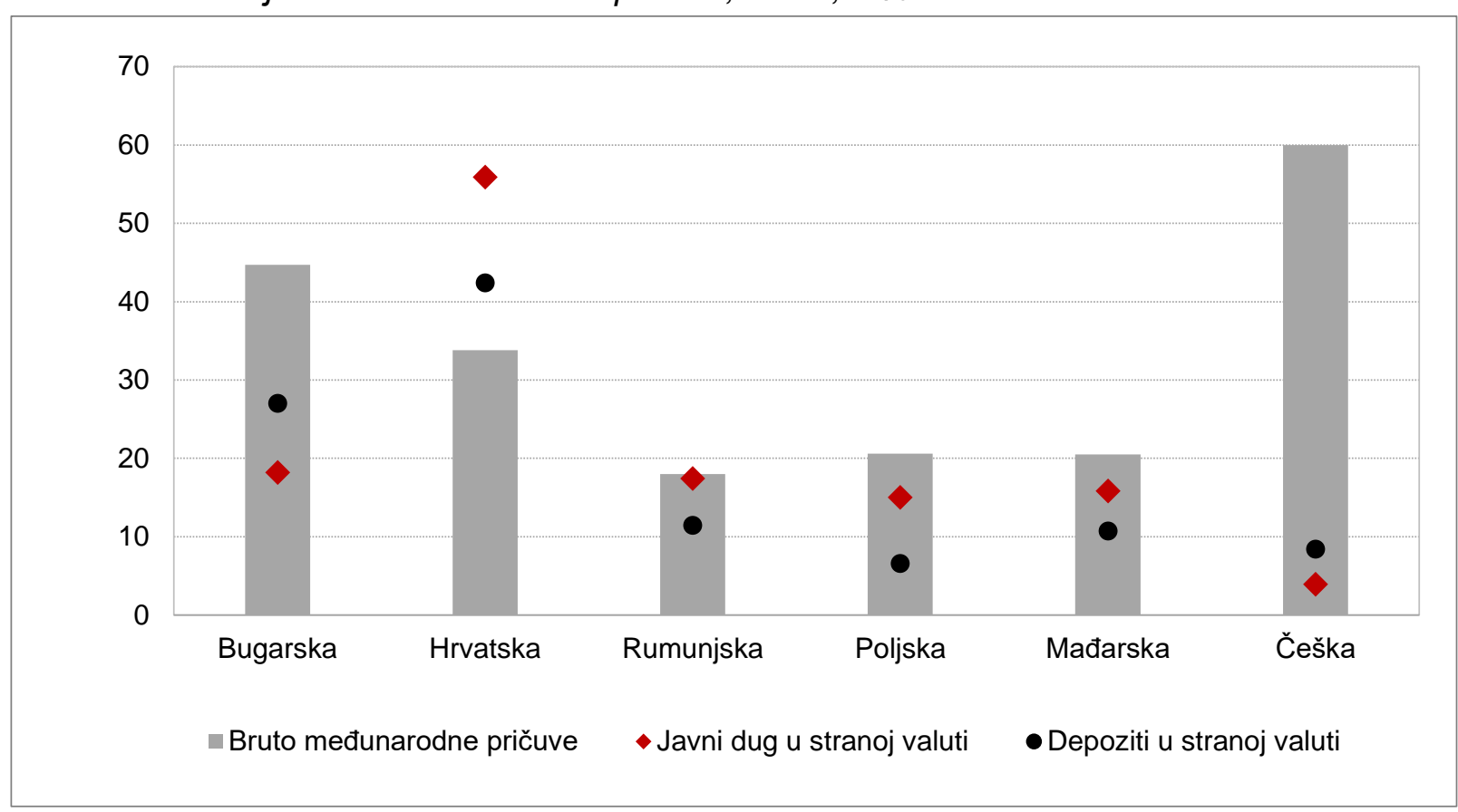

Izvor: Eurostat (2020c); nacionalne središnje banke; izračun autora

Dakako, usporedba predstavljena na Grafikonu 8. ne daje cjelovit uvid u izloženost tih država valutnom riziku. Primjerice, na grafikonu uopće nisu prikazani podaci za inozemni dug privatnog sektora. Nadalje, podaci o javnom dugu u stranoj valuti uključuju i obveze koje su vezane uz stranu valutu, ali koje se podmiruju u kunama, što znači da država nije dužna koristiti stranu valutu kada otplaćuje taj dug. Drugim riječima, otplata tog dijela javnog duga ne stvara pritisak na međunarodne pričuve. Naposljetku, usporedba prikazana na Grafikonu 8. ne uzima u obzir to da devizni depoziti nisu jedini kanal kojim bi privatni sektor mogao izazvati iscrpljivanje međunarodnih pričuva. Depoziti u domaćoj valuti i gotov novac koji se nalazi u optjecaju također bi mogli pridonijeti iscrpljivanju pričuva, kad bi građani počeli s tim sredstvima intenzivno kupovati stranu valutu zbog bojazni da će domaća valuta snažno deprecirati. Premda relativna razina deviznih depozita nije savršen pokazatelj, ona ipak daje važne informacije jer otkriva u kojoj mjeri građani vjeruju vlastitoj valuti (Honohan, 2007.). Ako je povjerenje prema valuti nisko, što se prepoznaje u visokom udjelu deviznih depozita u ukupnim depozitima, veća je vjerojatnost da će građani u slučaju deprecijacije nastojati preostala sredstva koja drže u domaćoj valuti što prije konvertirati u stranu valutu. U takvim uvjetima, razumno je pretpostaviti da bi u slučaju deprecijacije tečaja visoko euroizirane države poput Hrvatske i Bugarske doživjele brži gubitak međunarodnih pričuva nego Poljska i Češka, u kojima je veće povjerenje u domaću valutu. 


\subsection{MAKROEKONOMSKI FUNDAMENTI U DRŽAVAMA ČLANICAMA EU-A KOJE NISU DIO EUROZONE}

U razdoblju nakon svjetske financijske krize države SIE ostvarivale su stabilan, uravnotežen gospodarski rast podržan ekspanzivnom monetarnom politikom i oporavkom glavnih vanjskotrgovinskih partnera iz EU-a. U usporedbi s razdobljem prije krize to je značajna prilagodba u strukturi rasta. Naime, do izbijanja krize 2008. većina tih država bilježila je snažnu ekspanziju temeljenu na domaćoj potražnji koju su pak podgrijavali obilni priljevi dužničkog kapitala. Razdoblje obilnih kapitalnih tokova okončano je pojavom svjetske krize, pa su se države SIE morale tome prilagoditi stezanjem privatne i javne potrošnje. U Mađarskoj i Rumunjskoj odljev kapitala i potrebna makroekonomska prilagodba bili su toliko snažni da su vlasti posegnule za financijskom pomoći MMF-a i EU-a kako bi mogle lakše podnijeti tranziciju. lako je prilagodba gospodarstva u početku bila neugodna, ona je postavila temelje za zdrav oporavak u sljedećim godinama.

Podaci prikazani na Grafikonu 9. potvrđuju znatno poboljšanje situacije u državama SIE nakon svjetske financijske krize. Nekada visoki manjkovi na tekućem računu smanjili su se ili su čak zamijenjeni viškovima, dok je stanje međunarodnih ulaganja primjetno poraslo u većini slučajeva, uglavnom zbog smanjenja dužničkih obveza i povećanja međunarodnih pričuva. ${ }^{21}$ Kada je riječ o javnim financijama, nakon nekoliko godina visokih proračunskih manjkova uzrokovanih recesijom, u razdoblju od 2015. do izbijanja pandemije virusa COVID-19 većina država SIE imala je dobra fiskalna ostvarenja potpomognuta rastom nominalnog BDP-a i posljedično boljim prikupljanjem proračunskih prihoda. Omjeri javnog duga i BDP-a ubrzano su se smanjivali, što se odnosi i na Hrvatsku i Mađarsku, čije su razine duga najviše u ovoj skupini država. Povoljna fiskalna kretanja prekinuta su, međutim, početkom 2020. pod utjecajem visokih ekonomskih troškova pandemije virusa COVID-19.

\footnotetext{
${ }^{21}$ Češka je poseban slučaj s obzirom na to da je od 2007.-2018. zabilježila i povećanje međunarodnih pričuva i povećanje dužničkih obveza. Takva su kretanja jednim dijelom bila posljedica odluke češke središnje banke iz studenoga 2013. da uvede donji prag za devizni tečaj s ciljem poticanja gospodarskog oporavka i otklanjanja deflatornih pritisaka. Naime, ta je odluka potaknula znatne špekulativne kapitalne priljeve u Češku jer su investitori očekivali da će češka kruna zamjetno ojačati prema euru jednom kada prag bude ukinut. Samo u 2017. središnja je banka na deviznom tržištu otkupila čak 42,5 mlrd eura (22\% BDP-a) kako bi obranila tečajni prag (Czech National Bank, 2018.).
} 


\section{Grafikon 9.}

Platna bilanca, stanje međunarodnih ulaganja i pričuve država SIE, 2007. i 2018., u \% BDP-a a) tekući račun platne bilance i stanje međunarodnih ulaganja

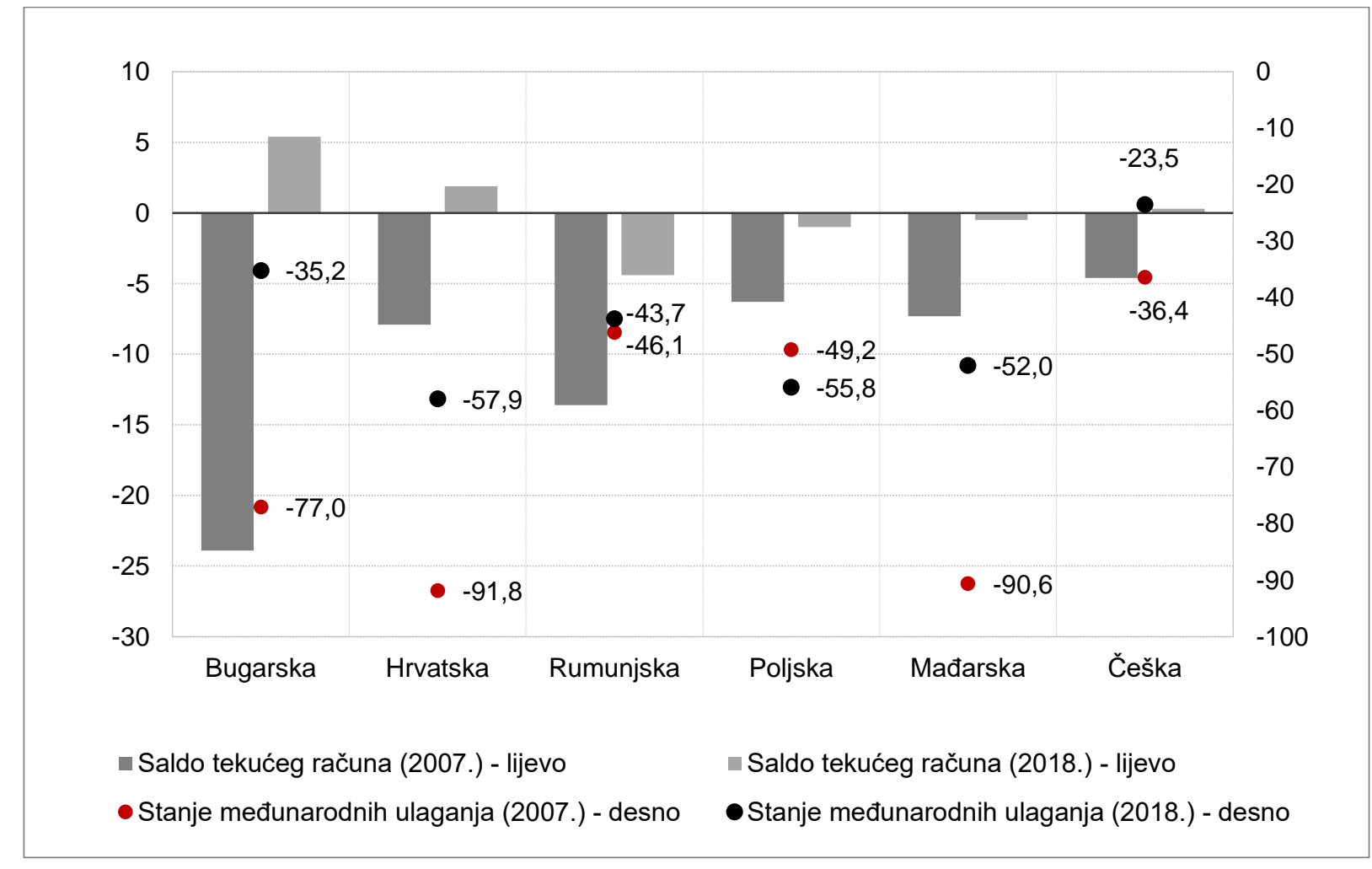

b) međunarodne pričuve

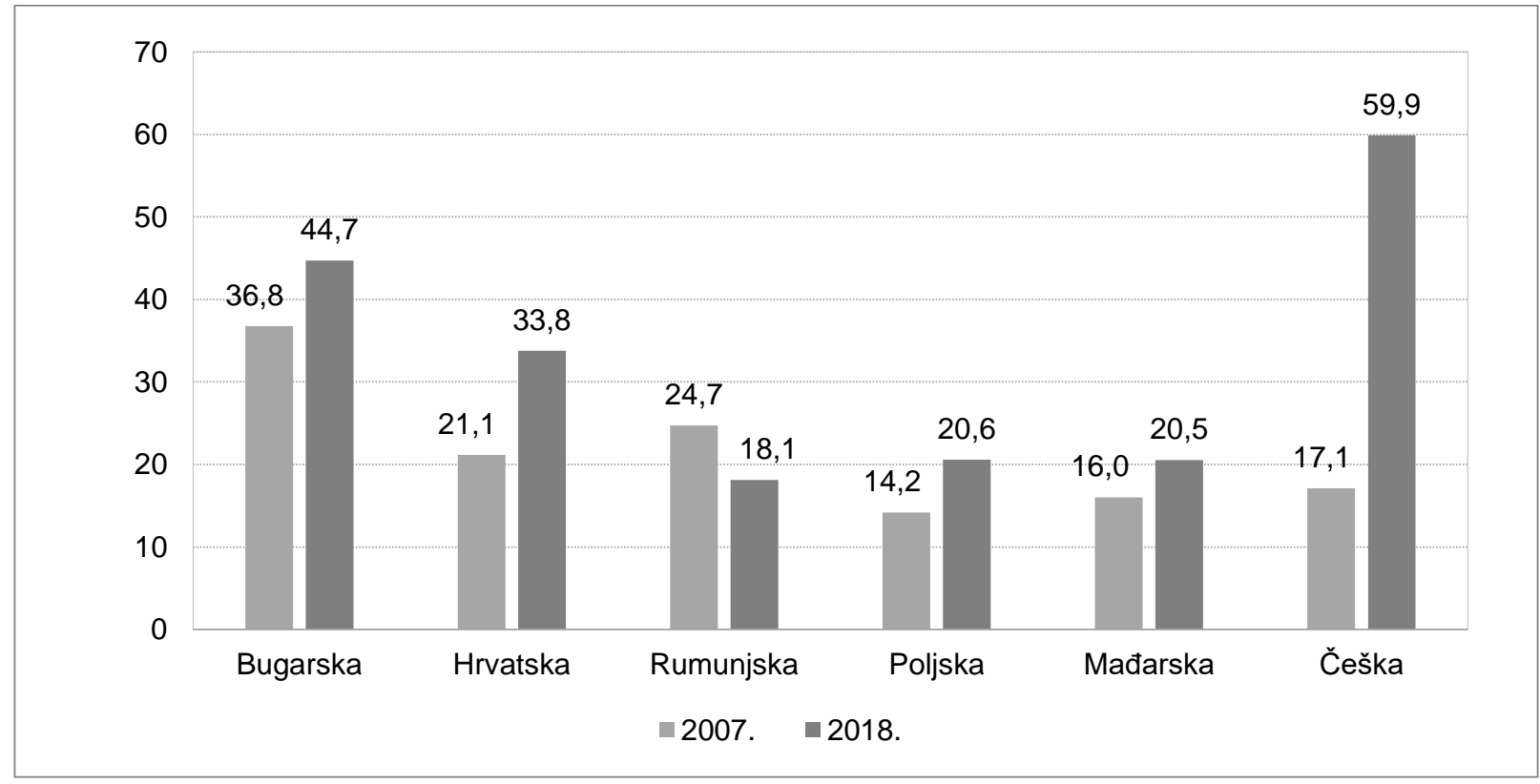

Izvor: IMF (2020.d) 


\section{Grafikon 10.}

Fiskalni pokazatelji za države SIE, 2017.-2018., u \% BDP-a
a) proračunski saldo
b) bruto dug države

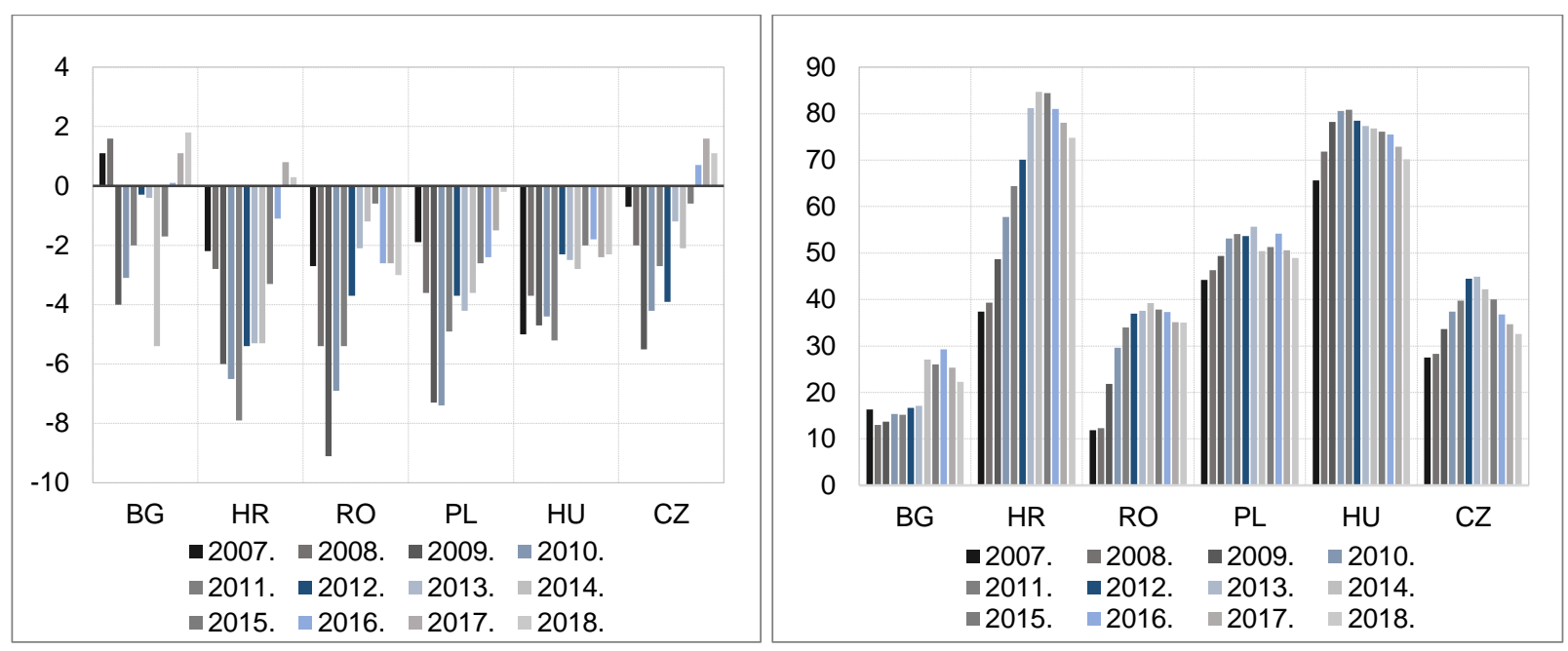

Izvor: Eurostat (2020a)

Postoje i drugi činitelji, osim snažnijih vanjskih i fiskalnih pokazatelja, koji su također pridonijeli tome što se izloženost država iz SIE valutnom riziku smanjila. Jedan od njih je umjereno smanjenje kreditne i depozitne euroizacije u razdoblju nakon 2008. (Dumičić, Ljubaj i Martinis, 2017.). Naime, dugotrajno razdoblje vrlo ekspanzivne monetarne politike na globalnoj razini omogućilo je središnjim bankama SIE da emitiraju znatne iznose likvidnosti u domaćoj valuti, a da pritom ne ugroze stabilnost deviznog tečaja. Banke su taj novokreirani višak likvidnosti iskoristile za odobravanje kredita u domaćoj valuti, pa se njihov udio u ukupnim kreditima povećao. U nekim se državama smanjila i depozitna euroizacija pod utjecajem odluke deponenata da premjeste sredstva položena na oročene devizne depozite - koji posljednjih godina nose kamatnu stopu od približno nula posto - na depozite po viđenju u domaćoj valuti (Ljubaj i Petrović, 2016.). Osim toga, znatan višak likvidnosti u bankovnim sustavima SIE omogućio je vladama tih država da u određenoj mjeri zamijene inozemno zaduživanje s financiranjem kod domaćih banaka u domaćoj valuti. To se ogleda u blagom smanjenju udjela javnog duga nominiranog u stranoj valuti. U Hrvatskoj je, primjerice, u razdoblju od 2015.2018. udio nerezidenata u vlasničkoj strukturi javnog duga pao za 9 postotnih bodova (sa $41,6 \%$ na $32,7 \%$ ). Istodobno, za 8 postotnih bodova (sa $79,5 \%$ na $71,6 \%$ ) smanjio se udio duga u stranoj valuti u ukupnom javnom dugu.

Naposljetku, kada se raspravlja o osjetljivosti država SIE na valutni rizik, treba razmotriti i intenzitet ekonomske integriranosti tih država s eurozonom. Stupanj integracije važan je zato što je euro valuta u kojoj je nominiran najveći dio duga u stranoj valuti tih država. Neugodna iskustva nekih država s tržištima u nastajanju, o kojima se govori u drugom poglavlju, podsjećaju da za državu može biti vrlo rizično financiranje u jednoj od ključnih svjetskih valuta ako je intenzitet ekonomskih odnosa s državom koja emitira tu valutu nizak. Primjerice, države Latinske Amerike akumulirale su tijekom 1970-ih znatne iznose obveza u američkim dolarima, dok su njihove ekonomske veze sa SAD-om bile slabe. U takvim uvjetima postojao je rizik da monetarna politike američkog Feda neće uvijek odgovarati potrebama njihovih 
gospodarstava. ${ }^{22}$ Taj se rizik materijalizirao početkom 1980 -ih kada je Fed odlučio povećati ključne kamatne stope kako bi suzbio visoku inflaciju u zemlji. Nagli rast kamatnih stopa otežao je državama Latinske Amerike servisiranje duga nominiranog u dolarima: ne samo da su porasle kamatne stope na dug nego su i njihove nacionalne valute oslabjele u odnosu na dolar, što je povećalo realnu vrijednost dolarskog duga.

Ovakav scenarij manje je vjerojatan u Europi, gdje je stupanj integriranosti država veći nego u Latinskoj Americi i drugim regijama (Grafikon 11.). Naime, s obzirom na to da su države članice EU-a koje nisu uvele euro visoko trgovinski i financijski integrirane s eurozonom, ekonomski šokovi koji pogađaju te države visoko su usklađeni sa šokovima koji zahvaćaju članice eurozone (Deskar-Škrbić, Kotarac i Kunovac, 2019.). Zbog toga, mala je vjerojatnost da će monetarna politika ESB-a - koja je prilagođena potrebama članica eurozone - u nekom trenutku imati dramatičan negativan učinak na valute i gospodarstva država članica koje nisu u eurozoni. To navodi na zaključak da je zaduživanje u eurima za snažno integrirane države članice EU-a vjerojatno manje rizično nego što je zaduživanje u američkim dolarima za države Latinske Amerike i azijske države.

\section{Grafikon 11.}

Geografska struktura robne razmjene odabranih država, 2018.

a) Države članice EU-a izvan eurozone

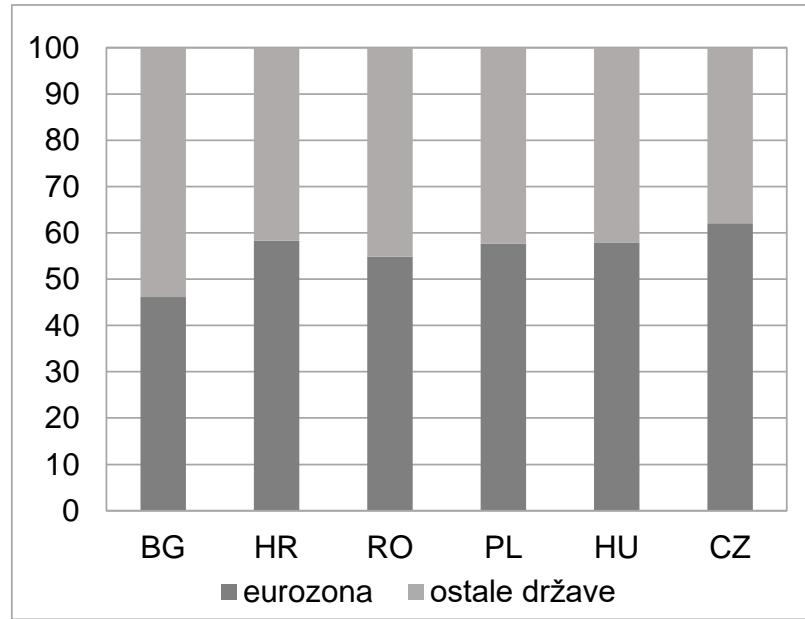

b) Države iz Latinske Amerike i Azije

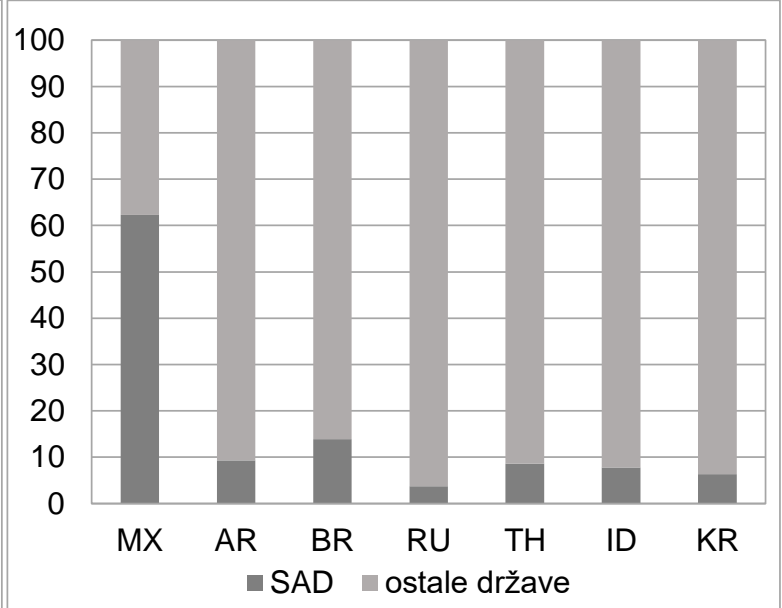

Izvor: IMF (2020c)

Na temelju rezultata jednostavne analize predstavljene u ovom poglavlju može se zaključiti da zaduživanje država u stranoj valuti nije značajan izvor rizika u EU-u. Ukupan iznos javnog duga nominiranog u stranoj valuti ili vezanog uz stranu valutu nizak je -tek nešto viši od $2 \%$ BDP-a EU-a. Kod samo dvije države - Bugarske i Hrvatske - dug u stranoj valuti (od čega se glavnina odnosi na dug u euru) čini veliku većinu ukupnog javnog duga. Čak i u ove dvije države vjerojatnost izbijanja valutne ili dužničke krize vrlo je mala, zahvaljujući njihovim dobrim

\footnotetext{
${ }^{22}$ Ako su gospodarski odnosi između dvije države slabog intenziteta, usklađenost njihovih poslovnih ciklusa vjerojatno će biti niska, pa monetarna politika krojena prema potrebama jedne od njih neće nužno odgovarati potrebama druge države. Primjerice, ako se država „sidro“ nalazi u zrelijoj fazi ekonomske ekspanzije od države „pratitelja“, država „sidro“ može odlučiti povećati kamatne stope kako bi spriječila moguće pregrijavanje svog gospodarstva. To bi, međutim, moglo usporiti rast u državi „pratitelju“ koja bi u takvoj situaciji preferirala nepromijenjenu monetarnu politiku.
} 
fiskalnim i vanjskim pokazateljima te visokim međunarodnim pričuvama. Otpornost ovih država očitovala se tijekom krize izazvane pandemijom virusa COVID-19 kada su obje uspjele provoditi izdašne programe fiskalnih poticaja, a da pritom nisu ugrozile stabilnost svojih valuta i javnih financija (Europska komisija, 2020.).

Ne iznenađuje činjenica da su upravo države koje su najviše izložene valutnom riziku prve među preostalim članicama EU-a izvan eurozone poduzele konkretne korake s ciljem uvođenja eura. Naime, nakon što su provele niz reformskih mjera na koje su se prethodno obvezale, u srpnju 2020. Bugarska i Hrvatska pristupile su Europskom tečajnom mehanizmu II (ERM II), koji predstavlja završni korak u postupku uvođenja eura. Rumunjske vlasti istaknule su da planiraju poduzeti iste korake u sljedećim godinama. Istodobno, ostale države članice koje nisu dio eurozone još uvijek nisu pokazale interes za uvođenje eura. To se djelomično može povezati s njihovom manjom izloženošću valutnom riziku. Drugim riječima, s obzirom na to da valutna neusklađenost u bilancama dužnika u tim državama nije toliko izražena, koristi od uvođenja eura i otklanjanja valutnog rizika ne čine se osobito velike iz njihove perspektive, pa ni uvođenje eura nije toliko privlačno kao cilj ekonomske politike.

\section{ZAKLJUČAK}

Postoje barem tri razloga zašto je za državu zaduživanje u stranoj rizičnije od zaduživanja u vlastitoj valuti. Prvo, visok udio deviznog javnog duga čini javne financije vrlo osjetljivima na fluktuacije deviznog tečaja. Ako tečaj deprecira, omjer javnog duga i BDP-a trenutačno će porasti, dok će se proračunski saldo pogoršati zbog viših kamatnih izdataka. Drugo, zaduženost u stranoj valuti čini državu ranjivom na nagle promjene u raspoloženju investitora, s obzirom na to da su investitori svjesni da se država može suočiti s nestašicom deviza ako veći broj njih istodobno odluči da više neće financirati tu državu. Treće, zaduživanje u stranoj valuti umanjuje kapacitet središnje banke da suzbije financijsku krizu ako se ona pojavi. Naime, ako investitori zaista odluče povući svoja sredstva s tržišta javnog duga i tako generiraju pritiske na valutu države, manevarski prostor središnje banke da se nosi s dužničkom i valutnom krizom bit će ograničen jer taj prostor u potpunosti ovisi o visini njezinih međunarodnih pričuva.

Kapacitet središnje banke da intervenira u vremenima kriza mnogo je veći u državama čiji je javni dug pretežno nominiran u domaćoj valuti. Čak i ako veći broj investitora odluči da više neće financirati državu, njezina središnja banka može emitirati dodatna sredstva kreditiranjem poslovnih banaka ili kupnjom vrijednosnica države na sekundarnom tržištu kako bi omogućila državi da refinancira svoje obveze. Upravo je to činio ESB tijekom europske dužničke krize, a isto to čini i nakon izbijanja pandemije virusa COVID-19 početkom 2020. Te dvije krize bi nesumnjivo bile puno teže da ESB nije reagirao na opisani način. U tom kontekstu, ovisnost države o zaduživanju u stranoj valuti definitivno se može smatrati „prokletstvom“, jer povećava vjerojatnost da se država suoči s iznenadnim padom povjerenja investitora $\mathrm{i}$ istodobno smanjuje njezin kapacitet za nošenje s dužničkom krizom ako do pada povjerenja investitora zaista dođe.

lako zaduženost države u stranoj valuti svakako jest izvor ranjivosti, ona ne mora nužno rezultirati dužničkom krizom. Povijesne epizode obrađene u ovom radu pokazuju da su 
dužničke i valutne krize vjerojatne kada se država pretjerano oslanja na kratkoročno financiranje, kada su međunarodne pričuve nedostatne, realni tečaj precijenjen, a kreditni rast prekomjeran. Suprotno tome, vjerojatnost izbijanja krize u pravilu će biti mala ako nacionalne vlasti provode razboritu ekonomsku politiku. Naime, ako je državni proračun uravnotežen, omjer javnog duga i BDP-a relativno nizak, a prosječno dospijeće javnog duga je dovoljno dugo, rizik da će država imati probleme pri refinanciranju duga bit će nizak, i to unatoč njegovoj nepovoljnoj valutnoj strukturi. Osim toga, poželjno je da međunarodne pričuve budu izdašne jer se tako investitorima poručuje da će država moći podmirivati svoje obveze čak i ako privremeno izgubi pristup međunarodnim financijskim tržištima. Bitno je i budno provođenje supervizije i regulative financijskog sektora, jer propadanje velikih banaka može nametnuti velik teret javnim financijama i tako ugroziti održivost javnog duga.

Javne financije država članica EU-a koje nisu dio eurozone ne doimaju se snažno izloženima valutnom riziku. U slučaju izraženije deprecijacije njihovih valuta, posljedično povećanje omjera javnog duga i BDP-a bilo bi blago u većini tih država. Čak ni države koje imaju visok udio duga u stranoj valuti u ukupnom javnom dugu, kao što su Bugarska i Hrvatska, ne bi trebale u bližoj budućnosti imati poteškoća s refinanciranjem javnog duga, s obzirom na njihova općenito dobra fiskalna i ukupna makroekonomska ostvarenja. Otpornost tih dviju država došla je do izražaja nakon izbijanja pandemije virusa COVID-19 kada su obje države uspjele primjenjivati znatne fiskalne poticaje te istodobno očuvati stabilnost svojih valuta $i$ javnih financija. Dugoročno gledano, međutim, ove dvije države imaju mnogo razloga za uvođenje eura. Pored činjenice da se njihov javni dug sastoji većinom od obveza nominiranih u euru, one se ističu i ustrajno visokim razinama kreditne i depozitne euroizacije, što je za njih dodatan izvor ranjivosti. Uvođenje eura donijelo bi značajne koristi Bugarskoj i Hrvatskoj u smislu manje izloženosti rizicima i veće otpornosti na financijske krize. Ne iznenađuje stoga što su upravo Bugarska i Hrvatska prve među preostalim državama članicama EU-a izvan eurozone iskazale interes za ulazak u ERM II i uvođenje eura. Kod ostalih država članica, osim Rumunjske, neto ekonomska korist od uvođenja eura čini se manjom, što djelomično objašnjava zašto njihove nacionalne vlasti ne planiraju započeti postupak uvođenja eura u skorije vrijeme. 


\section{LITERATURA}

1. Abiad, A., 2003. Early-Warning Systems: A Survey and a Regime Switching Approach. IMF Working Papers, br. 03/32. Washington: International Monetary Fund. https://doi.org/10.5089/9781451845136.00

2. Babecký, J. i sur., 2012. Banking, Debt, and Currency Crises. Early Warning Indicators for Developed Countries. Working Paper Series, br. 1485. Frankfurt am Main: European Central Bank.

3. Banco de Mexico, 2017. Quarterly Report October-December 2016. Mexico City: Banco de Mexico.

4. Brkić, M., 2019. Banking Distress in Europe in the Context of the Global Financial Crisis the Role of Capital Flows. Surveys, S-36. Zagreb: Hrvatska narodna banka.

5. Chang, R. i Velasco, A., 1998. Financial Crises in Emerging Markets: A Canonical Model. NBER Working Papers, br. 6606. Cambridge, MA: National Bureau of Economic Research.

6. Chang, R. i Velasco, A., 1999. Liquidity Crises in Emerging Markets: Theory and Policy. NBER MacroEconomics Annual, 14(1999), str. 11.-58. doi/10.1086/654376

7. Chang, R. i Velasco, A., 2002. Dollarization: Analytical Issues. NBER Working Papers, br. 8838. Cambridge, MA: National Bureau of Economic Research.

8. Claessens, S., Herring, R. J. i Schoenmaker, D., 2010. A Safer World Financial System: Improving the Resolution of Systemic Institutions. Geneva and London: International Center for Monetary and Banking Studies and Centre for Economic Policy Research.

9. Claessens, S., Schmukler, S. i Klingebiel, D., 2007. Government Bonds in Domestic and Foreign Currency: The Role of Institutional and Macroeconomic Factors. Review of International Economics, 15(2), str. 370.-413. https://doi.org/10.1111/j.14679396.2007.00682.x

10. Cole, H. L. i Kehoe, T. J., 2000. Self-Fulfilling Debt Crises. The Review of Economic Studies, 67(1), str. 91.-116. https://doi.org/10.1111/1467-937x.00123

11. Constancio, V., 2012. Contagion and the European Debt Crisis. Financial Stability Review, br. 16. Paris: Banque de France.

12. Czech National Bank, 2018. Annual Report 2017. Prague: Czech National Bank.

13. Danmarks Nationalbank, 2019. Danish Government Borrowing and Debt 2018, br. 1. Copenhagen: Danmarks Nationalbank.

14. Deskar-Škrbić, M., Kotarac, K. i Kunovac, D., 2019. The Third Round of the Euro Area Enlargement: Are the Candidates Ready. Working Papers, W-57. Zagreb: Hrvatska narodna banka.

15. Diamond, D. W. i Dybvig, P. H., 1983. Bank Runs, Deposit Insurance, and Liquidity. The Journal of Political Economy, 91(3), str. 401.-419. https://doi.org/10.1086/261155

16. Dumičić, M., 2015. A Brief Introduction to the World of Macroprudential Policy. Surveys, S18. Zagreb: Hrvatska narodna banka.

17. Dumičić, M., Ljubaj, I. i Martinis, A., 2018. Persistence of Euroisation in Croatia. Surveys, S-31. Zagreb: Hrvatska narodna banka.

18. Eichengreen, B. i Hausmann, R., 1999. Exchange Rates and Financial Fragility. NBER Working Papers, br. 7418. 
19. Eichengreen, B., Hausmann, R. i Panizza, U., 2003. Currency Mismatches, Debt Intolerance and Original Sin: Why They Are Not the Same and Why it Matters? NBER Working Papers, br. 10036. https://doi.org/10.3386/w10036

20. Eichengreen, B., Rose, A. K. i Wyplosz, C., 1995. Exchange Market Mayhem: the Antecedents and Aftermath of Speculative Attacks. Economic Policy, 10(21), str. 249.-312. https://doi.org/10.2307/1344591

21. European Commission, 2020. European Economic Forecast - Spring 2020. Brussels: European Commission.

22. Eurostat, 2020a. Government finance statistics. Nouxelles: Eurostat.

23. Eurostat, 2020b. National accounts statistics. Nouxelles: Eurostat.

24. Federal Deposit Insurance Corporation, 1997. An Examination of the Banking Crises of the 1980s and Early 1990s, Volume 1. Washington, DC: Federal Deposit Insurance Corporation.

25. Flood, R. P. i Marion, N. P., 1996. Speculative Attacks: Fundamentals and Self-Fulfilling Prophecies. NBER Working Papers, br. 5789. Cambridge, MA: National Bureau of Economic Research. https://doi.org/10.3386/w5789

26. Frankel, J. A. i Rose, A. K., 1996. Currency Crashes in Emerging Markets: An Empirical Treatment. International Finance Discussion Papers, br. 534. Washington, DC: Board of Governors of the Federal Reserve System.

27. Gros, D., Alcidi, C. i Giovanni, A., 2012. Central Banks in Times of Crisis. The FED versus the ECB. Paper presented at the European Parliament's Committee on Economic and Monetary Affairs Monetary Dialogue with the ECB, July 9.

28. Hausmann, R., Panizza, U. i Stein, E., 2001. Why Do Countries Float the Way They Float? Journal of Development Economics, 66(2), str. 387.-414. https://doi.org/10.1016/s03043878(01)00168-7

29. Higgins, M. i Klitgaard, T., 2014. Saving Imbalances and the Euro Area Sovereign Debt Crisis. Current Issues in Economics and Finance, 17(5), str. 1.-11. https://doi.org/10.2139/ssrn.1925018

30. Honohan, P., 2007. Dollarization and Exchange Rate Fluctuations. World Bank Policy Research Working Papers, br. 4172. Washington, DC: World Bank https://doi.org/10.1596/1813-9450-4172

31. HNB, 2012. Godišnje izvješće za 2011. Zagreb: Hrvatska narodna banka.

32. HNB, 2020. Bilten, br. 261. Zagreb: Hrvatska narodna banka.

33. IMF, 2009. Republic of Latvia: Request for Stand-By Arrangement - Staff Report. IMF Country Reports, br. 09/3. Washington, DC: International Monetary Fund.

34. IMF, 2020a. World Economic Outlook, April 2020: The Great Lockdown. Washington, DC: International Monetary Fund.

35. IMF, 2020b. Monetary and financial statistics. Washington: International Monetary Fund. 36. IMF, 2020c. Direction of Trade Statistics. Washington: International Monetary Fund.

37. IMF, 2020d. Balance of payments statistics and international investment positions. Washington: International Monetary Fund.

38. Kaminsky, G. L. i Reinhart, C. M., 1999. The Twin Crises: The Causes of Banking and Balance-of-Payments Problems. American Economic Review, 89(3), str. 473.-500. https://doi.org/10.1257/aer.89.3.473 
39. Kaminsky, G. L., Reinhart, C. M. i Végh, C. A., 2005. When It Rains, It Pours: Procyclical Capital Flows and Macroeconomic Policies. U M. Gertler and K. Rogoff, ur. NBER Macroeconomics Annual, 19(2004). Cambridge, MA: National Bureau of Economic Research, str. 11.-53.

40. Kaminsky, G., Lizondo, S. i Reinhart, C., 1998. Leading Indicators of Currency Crises. Staff Papers, 45(1), str. 1.-48. https://doi.org/10.2307/3867328

41. Kruger, M., Osakwe, P. N. i Page, J., 1998. Fundamentals, Contagion and Currency Crises: An Empirical Analysis. Working Papers, br. 98-10. Ottawa:Bank of Canada.

42. Ljubaj, I. i Petrović, S., 2016. A Note on Kuna Lending. Surveys, S-21. Zagreb: Hrvatska narodna banka.

43. Ljubaj, I., 2019. Međunarodne pričuve, tečajne razlike i financijski rezultat poslovanja HNBa. Pregledi, P-45. Zagreb: Hrvatska narodna banka.

44. Micossi, S., 2015. The Monetary Policy of the European Central Bank (2002-2015). CEPS Special Reports, br. 109. Brussels: Centre for European Policy Studies.

45. MoF, 2017. Public Debt Management Strategy 2017-2019. Zagreb: Ministarstvo financija Republike Hrvatske.

46. Obstfeld, M., 1986. Rational and Self-Fulfilling Balance-of-Payments Crises. NBER Working Papers, br. 1486. Cambridge, MA: National Bureau of Economic Research. https://doi.org/10.3386/w1486

47. Obstfeld, M., 1994. The Logic of Currency Crises. NBER Working Papers, br. 4640. Cambridge, MA: National Bureau of Economic Research. https://doi.org/10.3386/w4640

48. Purfield, C. i Rosenberg, C., 2010. Adjustment Under a Currency Peg: Estonia, Latvia and Lithuania During the Global Financial Crisis 2008-09. IMF Working Papers, br. 10/213. Washington, DC: International Monetary Fund. https://doi.org/10.5089/9781455205448.001

49. Ritschl, A., 2013. Reparations, Deficits, and Debt Default: the Great Depression in Germany. U N. Crafts and P. Fearon, ur. The Great Depression of the 1930s. Lesson for Today. London: Oxford University Press, str. 110.-139. https://doi.org/10.1093/acprof:oso/9780199663187.003.0004

50. Sachs, J., Tornell, A. i Velasco, A., 1996. The Collapse of the Mexican Peso: What Have We Learned? Economic Policy, 11(22), str. 13.-63. https://doi.org/10.2307/1344521

51. Sahay, R. i sur., 2014. Emerging Market Volatility: Lessons from the Taper Tantrum. IMF Staff Discussion Notes, br. 14/09. Washington, DC: International Monetary Fund. https://doi.org/10.5089/9781498318204.006

52. Swedish National Debt Office, 2019. Guidelines for Central Government Debt Management 2020. Stockholm: Swedish National Debt Office.

53. Vlaar, P. J. G., 2000. Early Warning Systems for Currency Crises. BIS conference papers, 8, str. 253.-274. 